\title{
Forests of Greece, Their Multiple Functions and Uses, Sustainable Management and Biodiversity Conservation in the Face of Climate Change
}

\author{
Konstantinos A. Spanos ${ }^{1 *}{ }^{(0)}$, Asimina Skouteri², Dionysios Gaitanis ${ }^{1}$, Panos V. Petrakis ${ }^{2}$, \\ Ioannis Meliadis' ${ }^{1}$, Panagiotis Michopoulos ${ }^{2}$, Alexandra Solomou², Panagiotis Koulelis², \\ Evangelia V. Avramidou2 ${ }^{2}$ (1)
}

${ }^{1}$ Hellenic Agricultural Organization-Dimitra, General Directorate of Agricultural Research, Forest Research Institute, Thessaloniki, Greece

${ }^{2}$ Hellenic Agricultural Organization-Dimitra, General Directorate of Agricultural Research, Institute of Mediterranean and Forest Ecosystems, Hellenic Agricultural Organization, Athens, Greece

Email: *kspanos@fri.gr

How to cite this paper: Spanos, K.A., Skouteri, A., Gaitanis, D., Petrakis, P.V., Meliadis, I., Michopoulos, P., Solomou, A., Koulelis, P. and Avramidou, E.V. (2021) Forests of Greece, Their Multiple Functions and Uses, Sustainable Management and Biodiversity Conservation in the Face of Climate Change. Open Journal of Ecology, 11, 374-406.

https://doi.org/10.4236/oje.2021.114026

Received: February 22, 2021

Accepted: April 24, 2021

Published: April 27, 2021

Copyright $\odot 2021$ by author(s) and ScientificResearch Publishing Inc. This work is licensed under the CreativeCommons Attribution International

License (CC BY 4.0).

http://creativecommons.org/licenses/by/4.0/

\section{(c) (i) Open Access}

\begin{abstract}
This is a review paper based on national and international literature, national inventories and empirical approach. A general overview of the forests, forest management and forest biodiversity of Greece are briefly summarized. The distribution of the main forest species and their ecosystems in the Geographic regions of Greece is presented in a tabular form. Their multiple functions and uses, their management type/regime, their risks and threats, protection and conservation measures are also synoptically described. Furthermore, adaptive forest management and silviculture as well as management of genetic diversity in order to face climate change are also analysed. Research priority areas on biodiversity and challenges for biodiversity research and related policy in Greece have been summarized. The new Rural Development Program (2014-2020), which is currently in the final phase of implementation, will take into consideration the forest itself and forest-related European and National legal obligations. Finally, major conclusions and research priority areas on future management and conservation of forests are highlighted.
\end{abstract}

\section{Keywords}

Greece, Forests, Multiple Uses, Management, Biodiversity, Conservation, Forest Policy, Climate Change, Strategic Targets

\section{Introduction}

Greece, in general, is a mountainous country with diverse geomorphology (high 
mountains, valleys, lowlands, lakes, rivers, etc.) (Figure 1). This geomorphology, in combination with the diverse geology (different bedrocks) and pedology (different soils) (Figure 2), diverse hydrological basins and dense hydrographic network (Figure 3), and a range of local microclimates (bioclimatic formations) (Figure 4), have provided habitats for different forest tree species (Figure 5).

Cold adapted species (e.g. beech, spruce, black pine, scotch pine, Bosnian pine, hybrid fir) are generally grown on the high mountains of north and central Greece (Figure $1 \&$ Figure 5). Some of these species (beech, spruce, Scots pine) form the south limits of their distribution in the Balkan Peninsula. Dry resistant

\section{D Geomorphological map of Greece with hydrographic net}

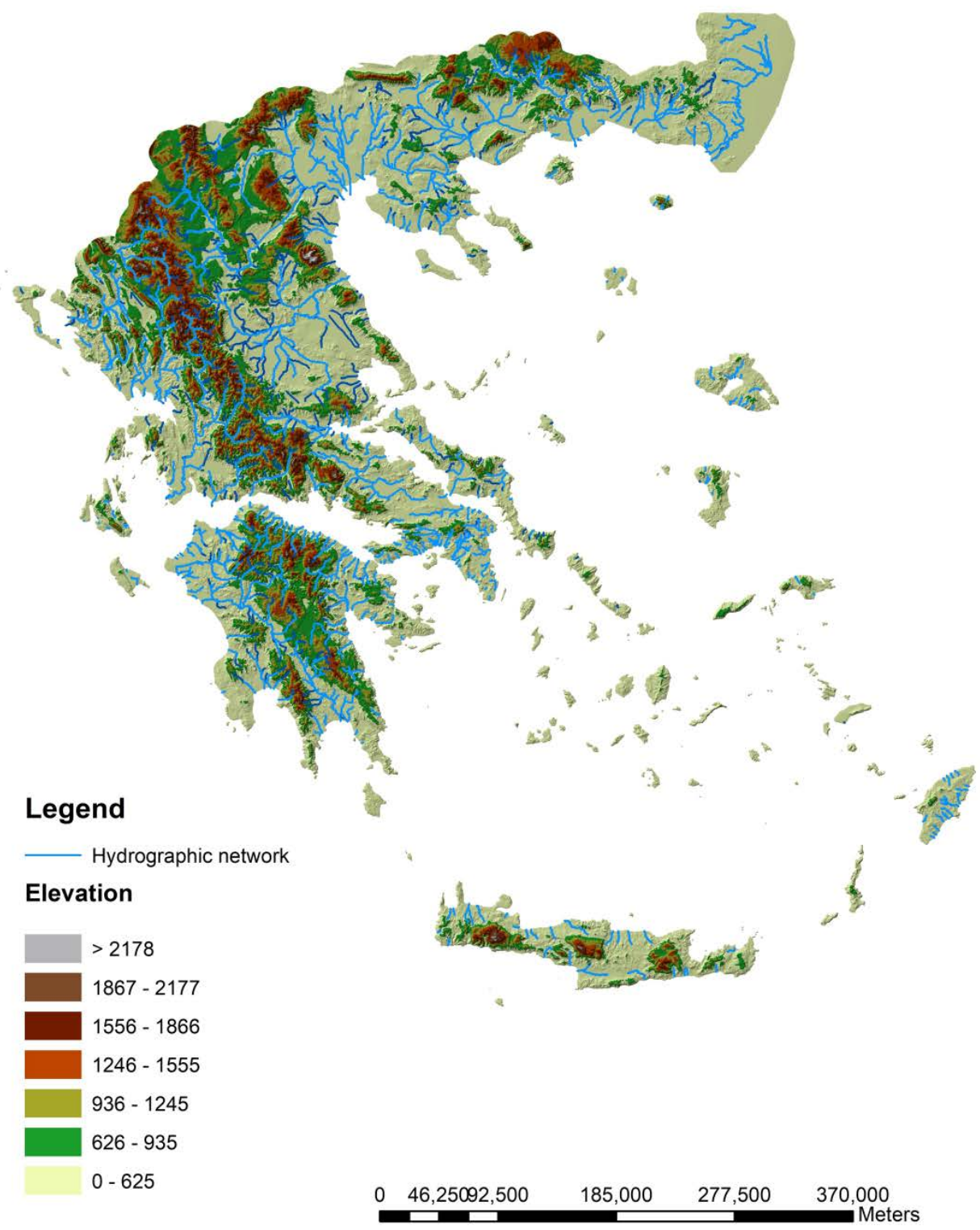

Figure 1. Geomorphological map of Greece (source: DTM data, modified by I. Meliadis). 


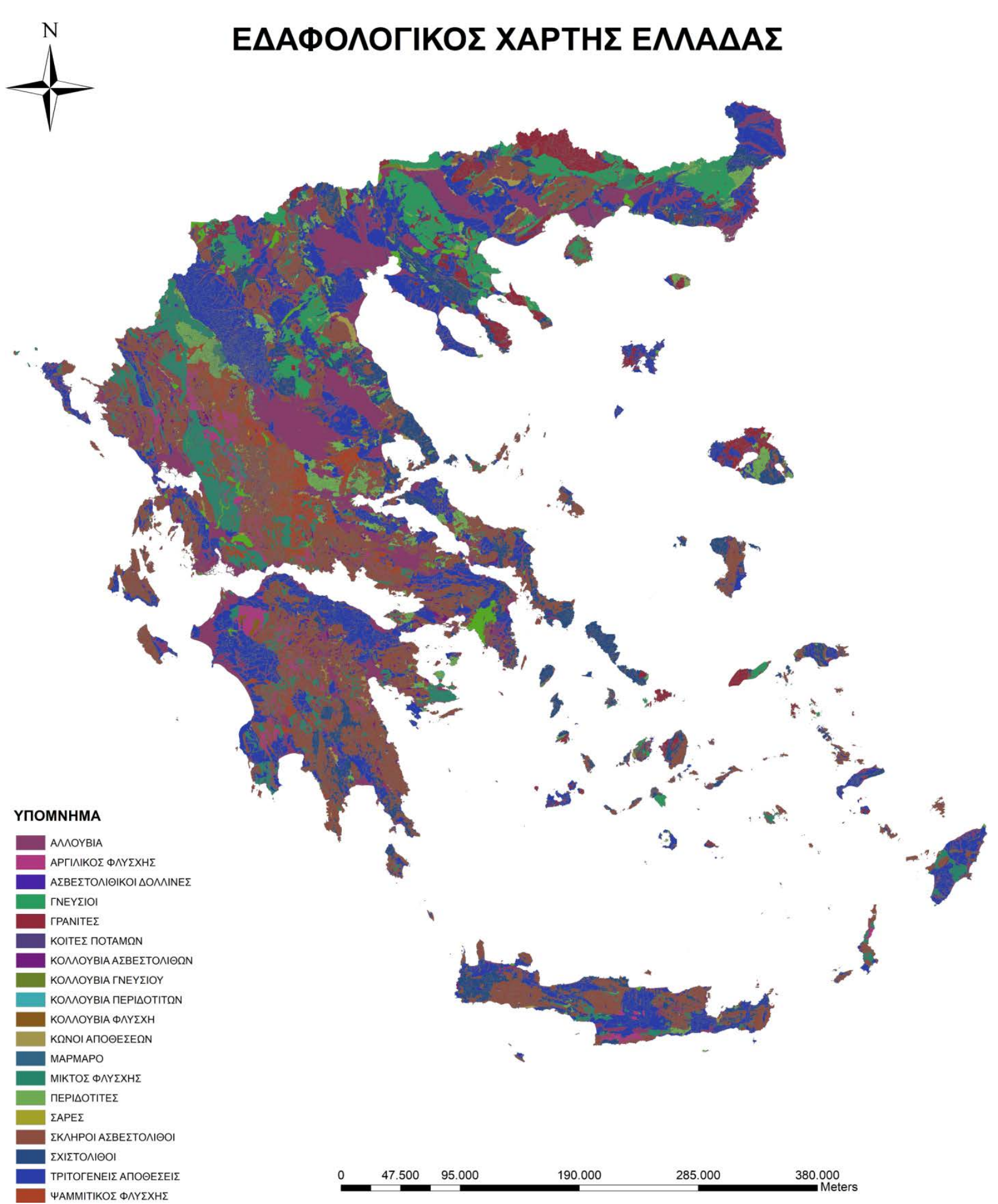

LEGEND: A $\Lambda \Lambda$ OYBIA/Alluvium, AРГI $\Lambda \mathrm{IKO} \Sigma \Phi \Lambda \Upsilon \Sigma \mathrm{XH} \Sigma /$ Clay flysh, A $\Sigma \mathrm{BE} \Sigma \mathrm{TO} \Lambda \mathrm{I} \Theta \mathrm{IKOI} \Delta \mathrm{O} \Lambda \Lambda \mathrm{INE} \Sigma /$ Dollines of limestones, $\Gamma \mathrm{NE} \Upsilon \Sigma \mathrm{IOI} /$ Gneiss, ГPANITE $\Sigma /$ Granite, KOITE $\Sigma \Pi O T A M \Omega N /$ Riverbeds, KO $\Lambda \Lambda$ OYBIAA $\Sigma$ BE $\Sigma T O \Lambda I \Theta \Omega N / C o l l u b i a$ of limestones,

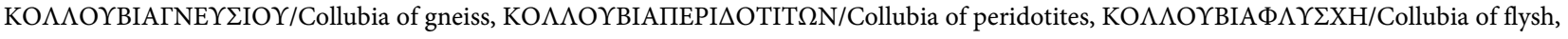
K $\Omega$ NOIAПO $\Theta E \Sigma \mathrm{E} \Omega$ N/Laying down cones, MAPMAPO/Marble, MIKTO $\Sigma \Phi \Lambda \Upsilon \Sigma \mathrm{XH} \Sigma /$ Mixed flysh, ПEPI $\Delta \mathrm{OTITE} \Sigma / \mathrm{Peridotites,} \Sigma$ APE $\Sigma / \mathrm{Screes}$,

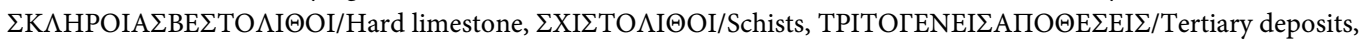
$\Psi$ AMMITIKO $\Sigma \Phi \Lambda \Upsilon \mathrm{XH} \Sigma /$ Sandstone of flysh.

Figure 2. Soil map of Greece (geology and soils) (source: Nakos 1991 [1]). 


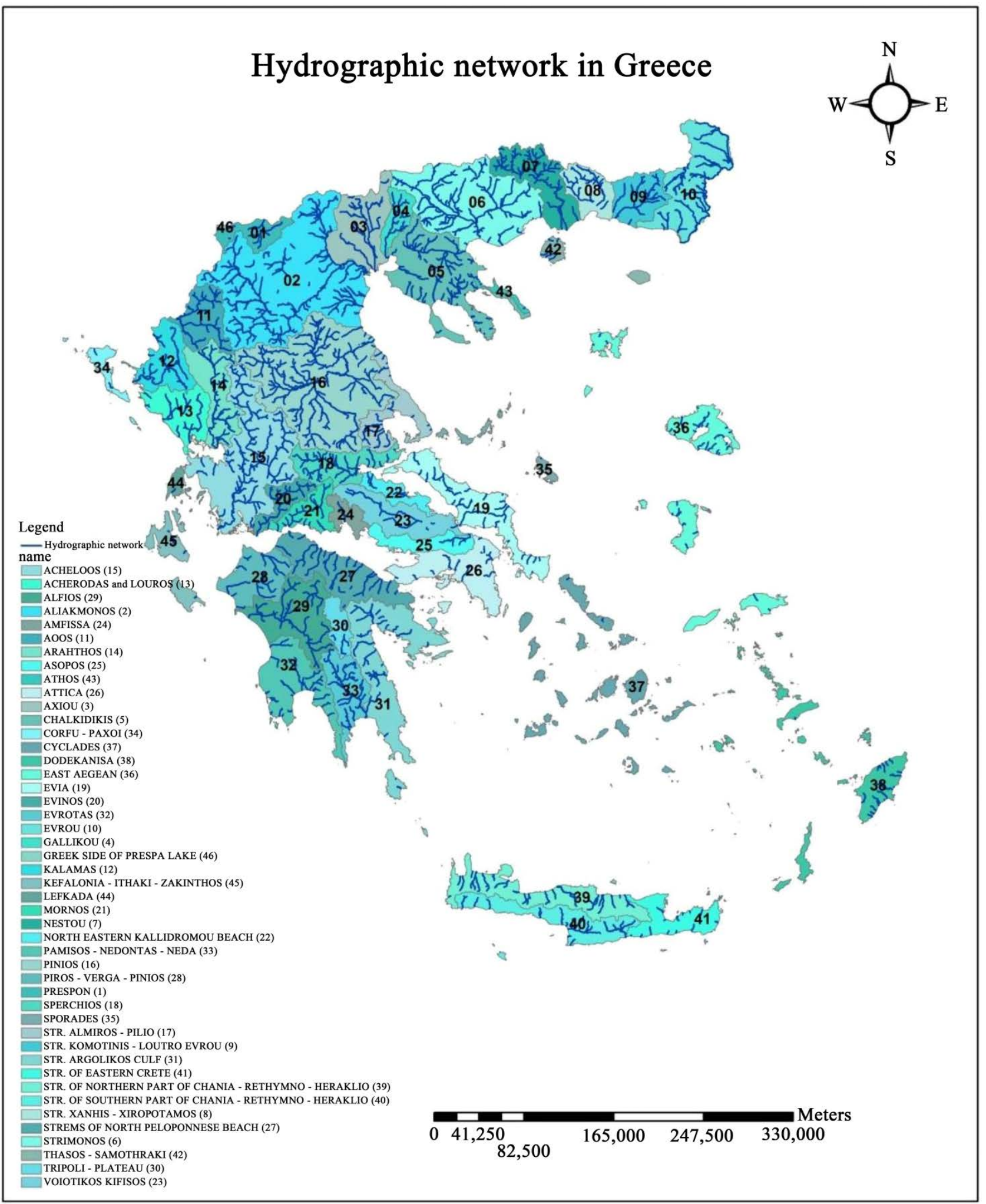

Figure 3. Map of hydrological basins and hydrographic network of Greece (source: Ministry of Agriculture, Directorate of Reforestations and Mountainous Hydrology 1983 (modified by I. Meliadis). 


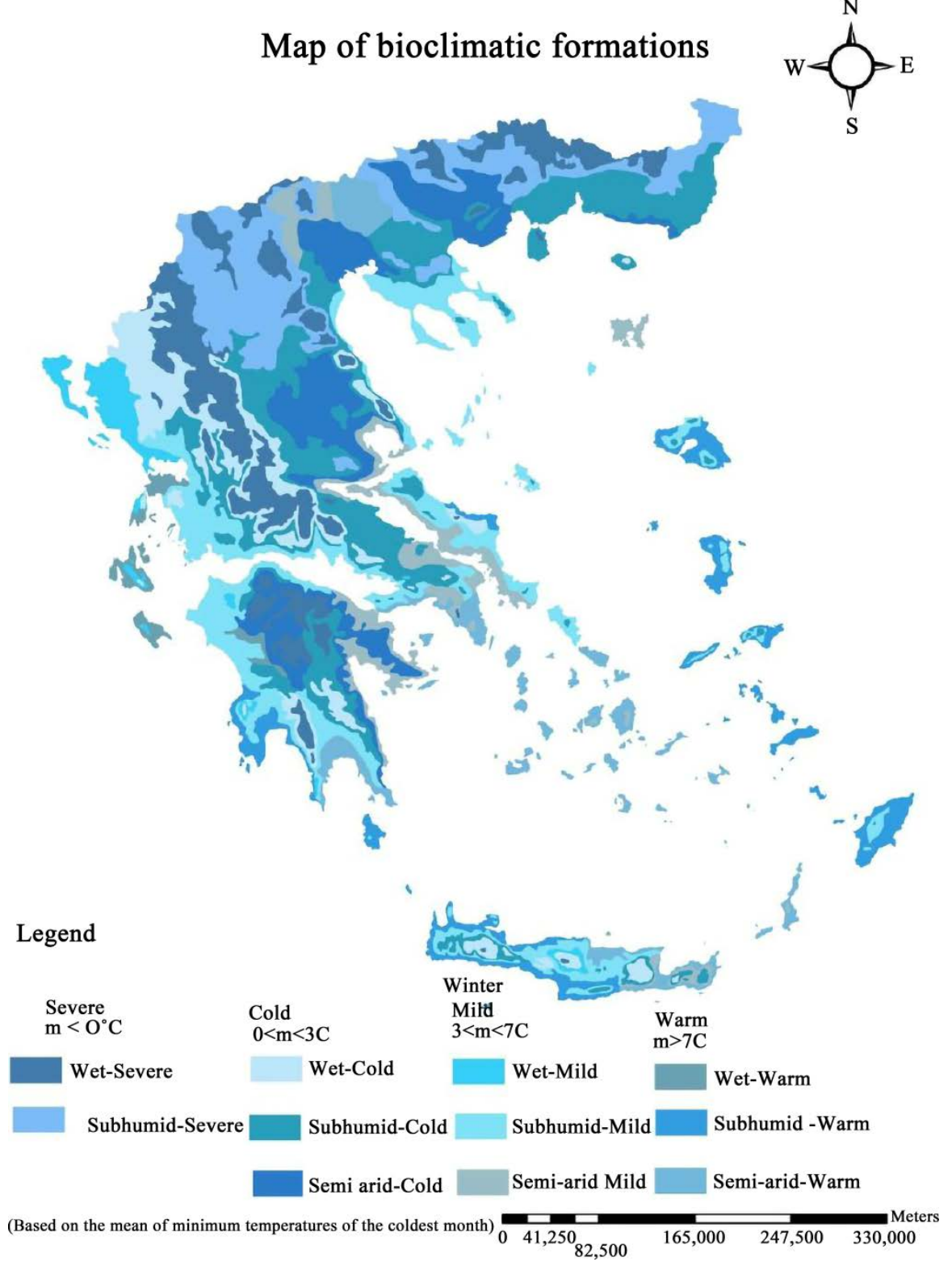

Figure 4. Map of bioclimatic formations of Greece (source: Ministry of Agriculture, General Directorate of Forests and Natural Environment, Forest Research Foundation, Mavrommatis 1980 [2] (modified by I. Meliadis).

and thermophilous species (e.g. Pinus brutia, Pinus halepensis, P. pinea), evergreen broadleaves (Quercus coccifera, Olea oleaster, Pistacia spp., Philyrea spp.) and thorny bushes (e.g. Sarcopoterium spinosum, Calycotome vilosa) are mainly found on the hilly lowlands, on coastal areas and dry sites on many islands (Figure 5).

Based on national and international information as well as on our long research experience on forestry and natural environment, we hope this overview work will provide useful information for the forests of Greece, forest biodiversity, forest management of the main forest species, protection and conservation of forest genetic resources in the face of climate change. Furthermore, this overview 


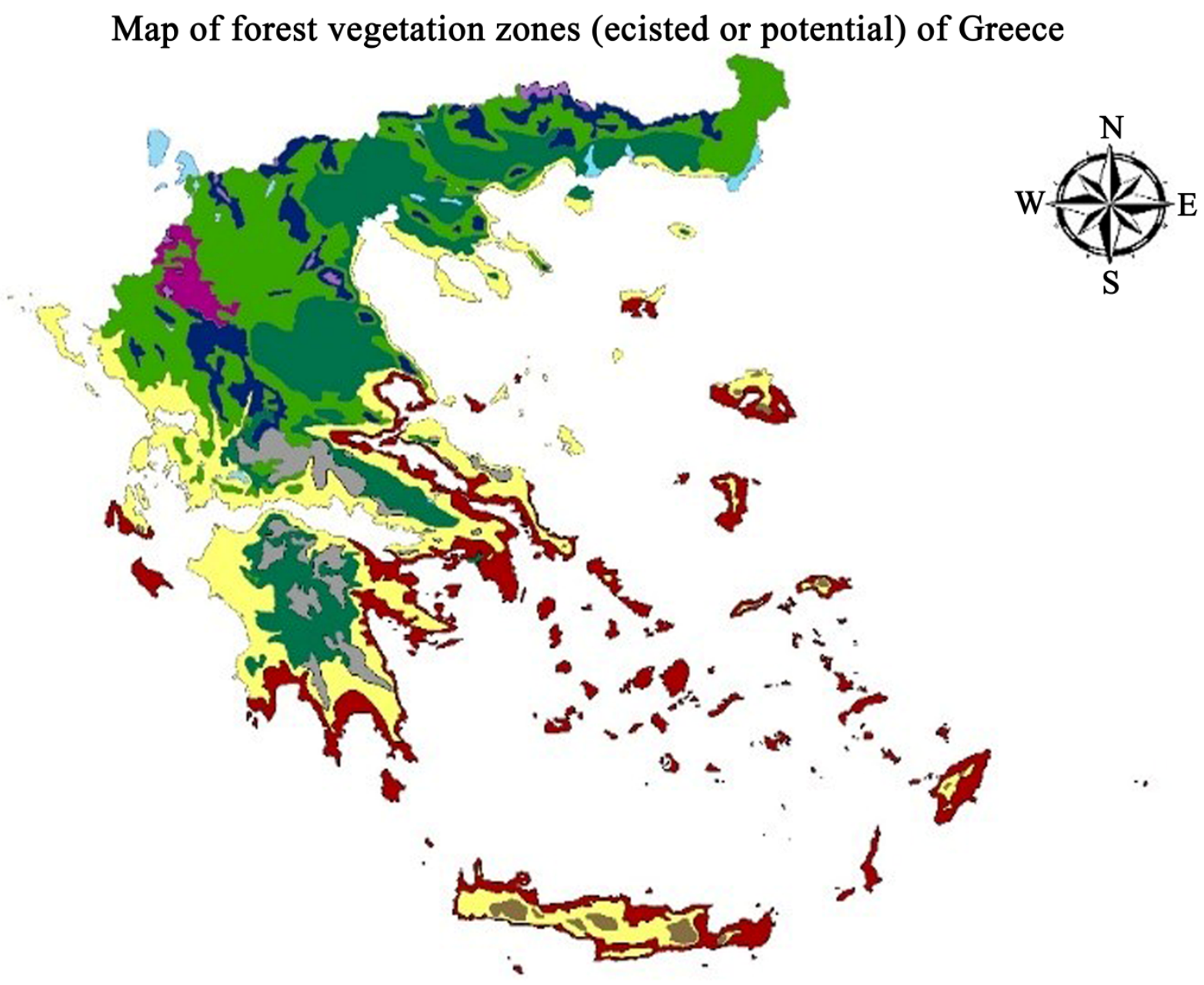

\section{Legend}

Oleo-ceratonion (Charact. Species: Olea europea var. sylvestris, Ceratonia siligua, varicus spiny bushes, Pistacia lentiscus, Quercus coccifera, Erica spp., Myrtus communis, Pinus halepensis, etc.)

Quercion ilicis (Charact. Species: Quercus ilex, Quercus coccifera, Fraxinus ornus, Arbutus spp., Erica spp., Phillyrea latifolia, Quercus pubescens, Pinus halepensis, P. brutia, etc.)

Cupression-Cocciferae (Charact. Species: Cupressus sempervirens, Quercus coccifera, etc.)

Ostryo-Carpinion (Charact. Species: Ostrya carpinifolia, Carpinus orientalis, Quercus coccifera, Quercus pubescens, Fraxinus ornus, Sorbus spp., Ulmus spp., Acer spp., etc.)

Quercion confertae (Charact. Species: Quercus conferta,

Quercus petraea, Sorbus spp., Tilia spp., Acer spp.,

Ostrya carpinifolia, Castanea vera, Fraxinus ornus, Quercus cerris, etc.)

Fagion moesiacae (Charact. Species: Fagus orientalis, Fagus sylvatica, Abies borissi regis, etc.)

Abietion cephalonicae (Charact. Species: Abies cephalonica, Pinus nigra var. palasiana, Quercus coccifera, etc.)

Pinetalia nigrae (Charact. Species: Pinus nigra var. austriaca, etc.)

Vacinio-Picetalia (Charact. Species: Picea abies, Pinus sylvestris, P. heldreichii, Betula pendula, etc.)

Azonal-riparian vegetation (tree species: Populus spp., salix spp., Platanus orientalis, Alnus glutinosa, Fraxinus angustifolia, Ulmus spp. Etc.)

Lakes

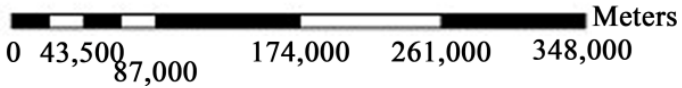

Figure 5. Map of forest vegetation zones (existed or potential) of Greece (source Dafis 1973, Mavromatis 1980, modified by K. Spanos 2018). 
work and inventory data will help new scientists and researchers, to set research priorities for the different forest species in the different regions of Greece in order to face climate change.

In Greece, most of the forests and forested lands are State owned (>74.1\%) (Figure 6). The rest are municipal (9.0\%), Church owned/other non-profit Foundations (10.4\%) and private (6.5\%) [3].

\section{Coverage and Distribution of the Main Forest Tree Species in Greece}

Of the total high forests, conifers cover about $41.60 \%$ whereas broadleaves cover $58.40 \%$ [4] (Figure 7) (Table 1). Coverage (\% of the total high forest species) of the main forest trees species in Greece is shown in Figure 8.

Of the total forests and forested lands around $41.3 \%$ are high forests, mostly naturally regenerated. The rest are partly forested areas, bush lands, grazing lands, rocky areas or bare lands (Table 1). The coverage of the main forest species

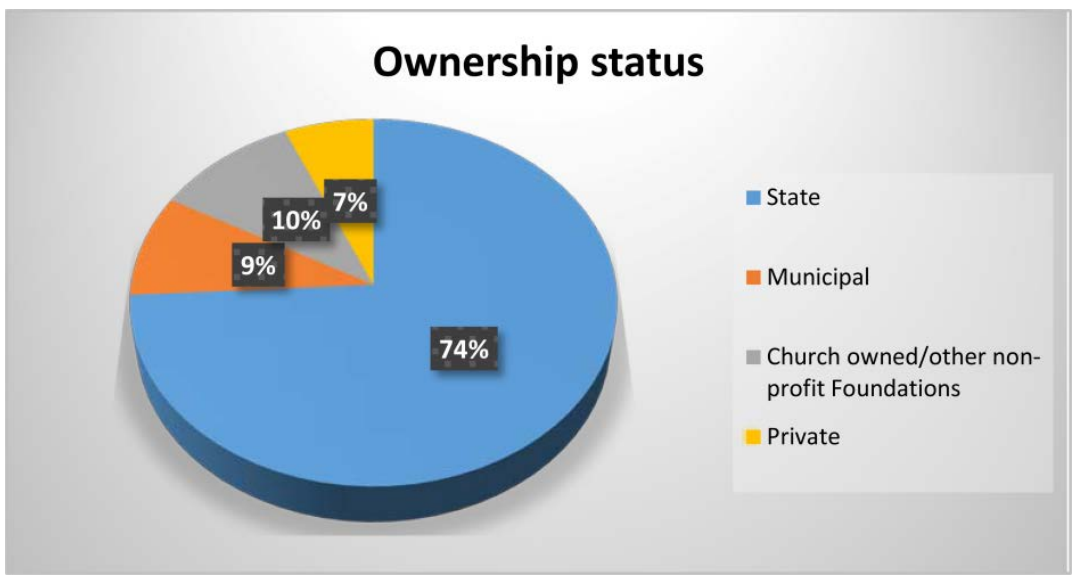

Figure 6. Ownership status of the forests and forest lands in Greece (State, Municipal, Church owned/other non-profit Foundations, Private lands) (source: Ministry of Agriculture 1992) [3].

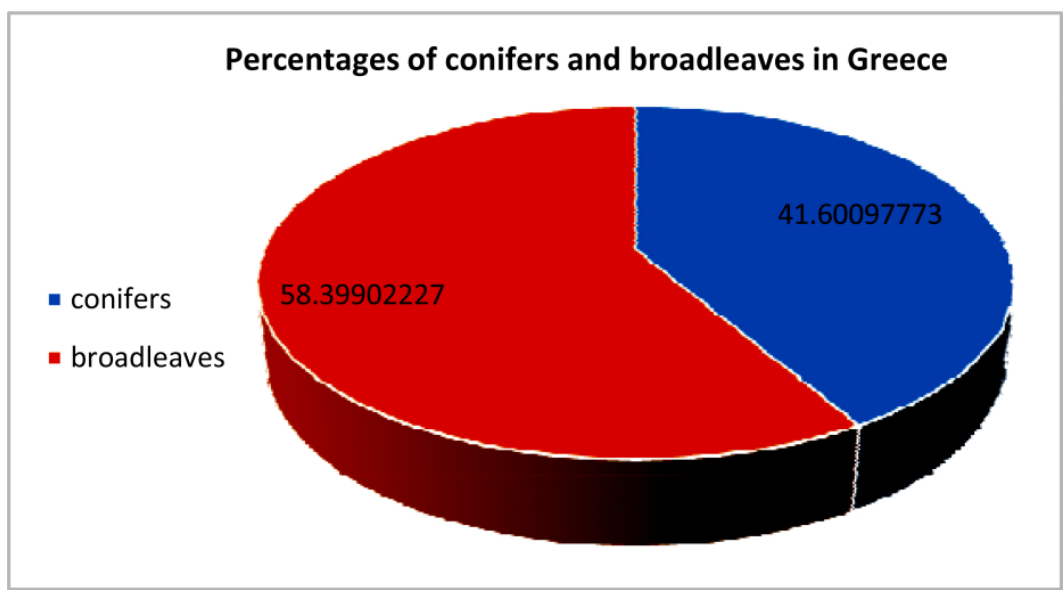

Figure 7. Percentages of conifers and broadleaves in Greece (based on the total high forests). 


\section{Coverage (\%) of the main forest species of Greece}

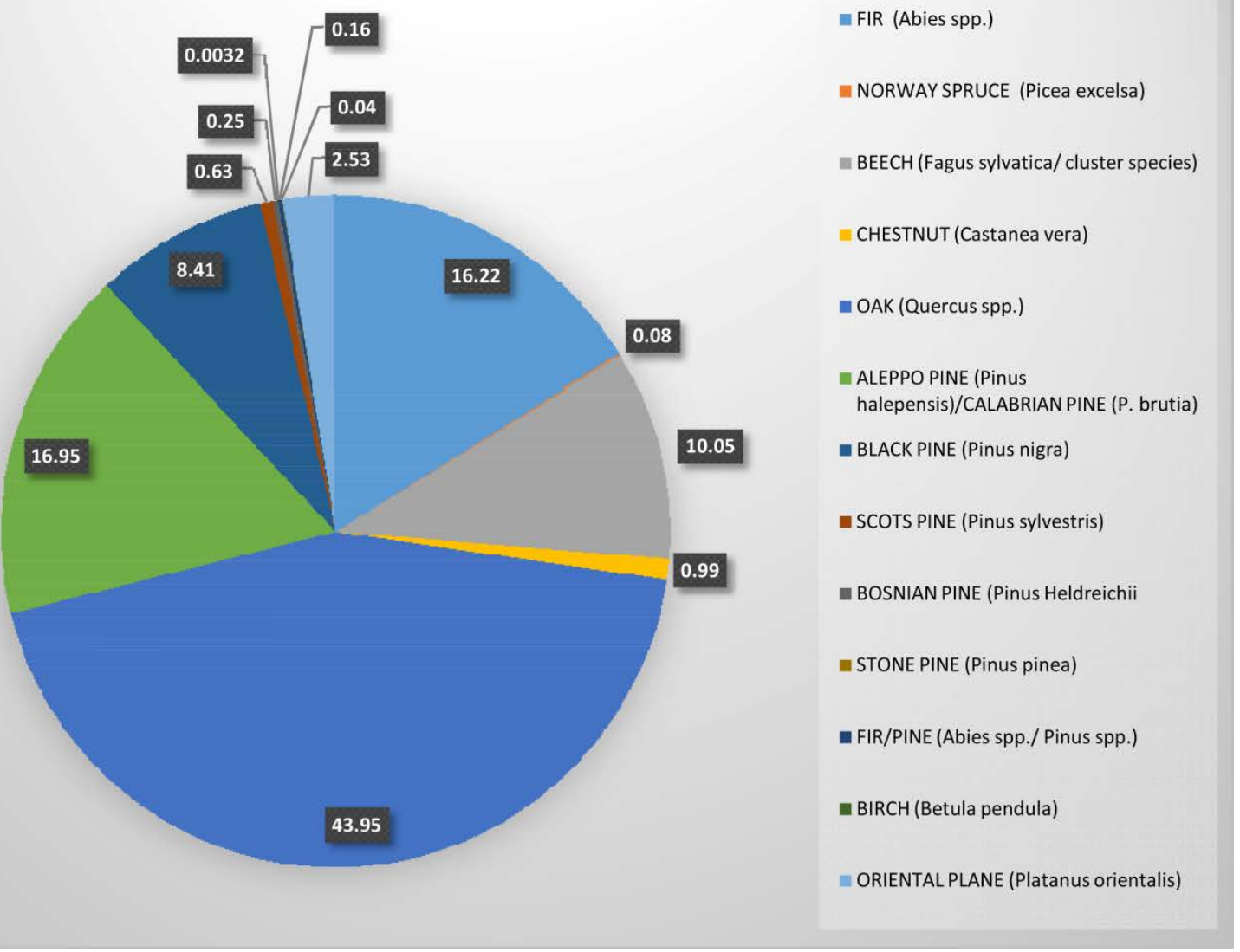

Figure 8. Coverage (\% of the total high forest species) of the main forest trees species in Greece (source: Ministry of Agriculture 1992) [3].

Table 1. Coverage (ha/\%) of the main forest species and other forest lands in Greece for the different Regions of Greece (source: Ministry of Agriculture 1992) [3].

\begin{tabular}{|c|c|c|c|c|c|c|c|c|c|c|c|c|c|c|}
\hline 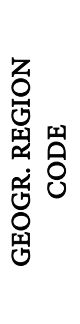 & 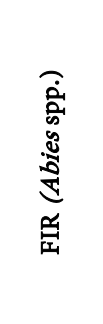 & 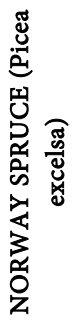 & 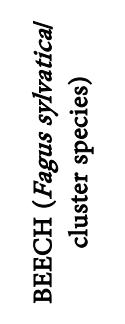 & 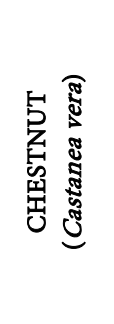 & 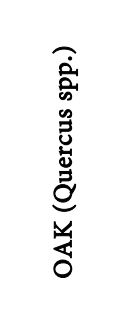 & 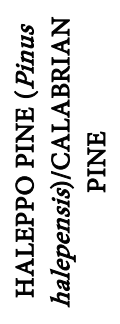 & 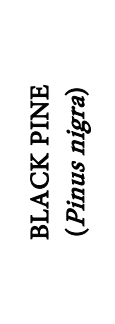 & 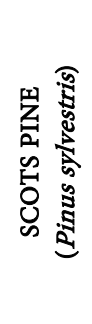 & 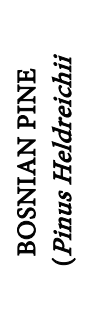 & 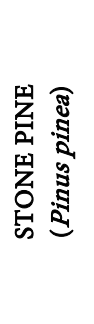 & 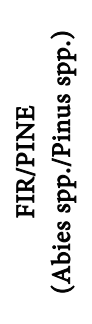 & 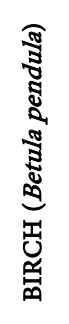 & 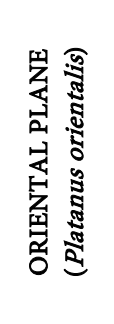 & 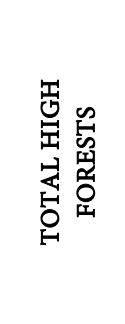 \\
\hline 1 & 2 & 3 & 4 & 5 & 6 & 7 & 8 & 9 & 10 & 11 & 12 & 13 & 14 & 15 \\
\hline \multirow[b]{2}{*}{1} & 2513 & 2754 & 77,369 & 4548 & 471,436 & 32,816 & 24,550 & 17,367 & 0.0 & 0.0 & 0.0 & 1437 & 11,699 & 646,489 \\
\hline & $0.39^{*}$ & 0.43 & 11.97 & 0.70 & 72.92 & 5.08 & 3.80 & 2.69 & 0.00 & 0.00 & 0.00 & 0.22 & 1.81 & $\begin{array}{c}69.45^{\star *} \\
45.67^{\star * *}\end{array}$ \\
\hline \multirow{2}{*}{2} & 2547.0 & 0.0 & $124,376.0$ & $13,786.0$ & $262,505.0$ & $54,111.0$ & $25,296.0$ & 3164.0 & 1815.0 & 0.0 & 2757.0 & 0.0 & $22,612.0$ & $512,969.0$ \\
\hline & 0.50 & 0.00 & 24.25 & 2.69 & 51.17 & 10.55 & 4.93 & 0.62 & 0.35 & 0.00 & 0.54 & 0.00 & 4.41 & $486,926.80$ \\
\hline \multirow{2}{*}{3} & 1430.0 & 0.0 & 58447.0 & 2850.0 & $146,009.0$ & 335.0 & $57,782.0$ & 424.0 & 2594.0 & 0.0 & 116.0 & 0.0 & 5434.0 & $275,421.0$ \\
\hline & 0.52 & 0.00 & 21.22 & 1.03 & 53.01 & 0.12 & 20.98 & 0.15 & 0.94 & 0.00 & 0.04 & 0.00 & 1.97 & $458,429.14$ \\
\hline 4 & $81,829.0$ & 0.0 & $38,091.0$ & 7529.0 & $126,637.0$ & 9512.0 & $26,470.0$ & 0.0 & 886.0 & 0.0 & 1054.0 & 0.0 & 8092.0 & $300,100.0$ \\
\hline
\end{tabular}


Continued

\begin{tabular}{|c|c|c|c|c|c|c|c|c|c|c|c|c|c|c|}
\hline & 27.27 & 0.00 & 12.69 & 2.51 & 42.20 & 3.17 & 8.82 & 0.00 & 0.30 & 0.00 & 0.35 & 0.00 & 2.70 & $391,921.38$ \\
\hline \multirow{2}{*}{5} & $30,046.0$ & 0.0 & $26,055.0$ & 448.0 & $158,299.0$ & 152.0 & $62,845.0$ & 0.0 & 3005.0 & 0.0 & 0.0 & 0.0 & 4913.0 & $277,245.0$ \\
\hline & 10.51 & 0.00 & 9.12 & 0.16 & 55.40 & 0.05 & 21.99 & 0.00 & 1.05 & 0.00 & 0.00 & 0.00 & 1.72 & $367,130.13$ \\
\hline \multirow{2}{*}{6} & 5417.0 & 0.0 & 0.0 & 0.0 & 208.0 & $15,001.0$ & 0.0 & 0.0 & 0.0 & 0.0 & 0.0 & 0.0 & 1251.0 & $21,877.0$ \\
\hline & 24.76 & 0.00 & 0.00 & 0.00 & 0.95 & 68.57 & 0.00 & 0.00 & 0.00 & 0.00 & 0.00 & 0.00 & 5.72 & $17,169.48$ \\
\hline \multirow{2}{*}{7} & $92,232.0$ & 0.0 & 417.0 & 286.0 & $120,865.0$ & $58,037.0$ & 5392.0 & 0.0 & 0.0 & 108.0 & 0.0 & 0.0 & 8013.0 & $285,350.0$ \\
\hline & 32.32 & 0.00 & 0.15 & 0.10 & 42.36 & 20.34 & 1.89 & 0.00 & 0.00 & 0.04 & 0.00 & 0.00 & 2.81 & 42.87 \\
\hline \multirow{2}{*}{8} & $239,504.0$ & 0.0 & $11,885.0$ & 1895.0 & $94,365.0$ & $115,035.0$ & $33,651.0$ & 0.0 & 0.0 & 0.0 & 0.0 & 0.0 & 16284.0 & $512,619.0$ \\
\hline & 46.72 & 0.00 & 2.32 & 0.37 & 18.41 & 22.44 & 6.56 & 0.00 & 0.00 & 0.00 & 0.00 & 0.00 & 3.18 & 44.10 \\
\hline \multirow{2}{*}{9} & 7507.0 & 0.0 & 0.0 & 0.0 & 209.0 & $65,547.0$ & 0.0 & 0.0 & 0.0 & 0.0 & 0.0 & 0.0 & 801.0 & $74,064.0$ \\
\hline & 10.14 & 0.00 & 0.00 & 0.00 & 0.28 & 88.50 & 0.00 & 0.00 & 0.00 & 0.00 & 0.00 & 0.00 & 1.08 & 38.21 \\
\hline \multirow{2}{*}{10} & $80,283.0$ & 0.0 & 0.0 & 1115.0 & $68,181.0$ & $54,254.0$ & $43,245.0$ & 0.0 & 0.0 & 0.0 & 1362.0 & 0.0 & 3200.0 & $251,640.0$ \\
\hline & 31.90 & 0.00 & 0.00 & 0.44 & 27.09 & 21.56 & 17.19 & 0.00 & 0.00 & 0.00 & 0.54 & 0.00 & 1.27 & 29.07 \\
\hline \multirow{2}{*}{11} & 0.0 & 0.0 & 0.0 & 416.0 & $12,293.0$ & $61,255.0$ & 2291.0 & 0.0 & 0.0 & 0.0 & 0.0 & 0.0 & 1874.0 & $78,129.0$ \\
\hline & 0.00 & 0.00 & 0.00 & 0.53 & 15.73 & 78.40 & 2.93 & 0.00 & 0.00 & 0.00 & 0.00 & 0.00 & 2.40 & 31.44 \\
\hline \multirow{2}{*}{12} & 0.0 & 0.0 & 0.0 & 0.0 & 6250.0 & $63,339.0$ & 0.0 & 0.0 & 0.0 & 0.0 & 0.0 & 0.0 & 624.0 & $70,213.0$ \\
\hline & 0.00 & 0.00 & 0.00 & 0.00 & 8.90 & 90.21 & 0.00 & 0.00 & 0.00 & 0.00 & 0.00 & 0.00 & 0.89 & 21.61 \\
\hline \multirow[b]{2}{*}{13} & 0.0 & 0.0 & 0.0 & 208.0 & 4582.0 & $38,337.0$ & 0.0 & 0.0 & 0.0 & 0.0 & 0.0 & 0.0 & 0.0 & $43,127.0$ \\
\hline & 0.00 & 0.00 & 0.00 & 0.48 & 10.62 & 88.89 & 0.00 & 0.00 & 0.00 & 0.00 & 0.00 & 0.00 & 0.00 & $\begin{array}{c}10.34 \\
5.17\end{array}$ \\
\hline \multirow{4}{*}{ Total } & 543,308 & 2754 & 336,640 & 33,081 & $1,471,839$ & 567,731 & 281,522 & 20,955 & 8300 & $108 \mathrm{~V}$ & 5289 & 1437 & 84,797 & \multirow{4}{*}{$\begin{array}{c}3,349,243 \\
41.29^{\mathrm{b}} \\
25.38^{\mathrm{c}}\end{array}$} \\
\hline & $16.22^{\mathrm{a}}$ & 0.08 & 10.05 & 0.99 & 43.95 & 16.95 & 8.41 & 0.63 & 0.25 & 0.0032 & 0.16 & 0.04 & 2.53 & \\
\hline & $6.70^{\mathrm{b}}$ & 0.03 & 4.15 & 0.41 & 18.14 & 7.00 & 3.47 & 0.26 & 0.10 & 0.0013 & 0.07 & 0.02 & 1.05 & \\
\hline & $4.12^{\mathrm{c}}$ & 0.02 & 2.55 & 0.25 & 11.15 & 4.30 & 2.13 & 0.16 & 0.06 & 0.0008 & 0.04 & 0.01 & 0.64 & \\
\hline
\end{tabular}

${ }^{*}=\%$ cover of the total high forests of the region, ${ }^{* *}=\%$ of the total high forests and forest lands of the region (see Table $1 /$ column 7 ), ${ }^{* *}=\%$ cover of the total area of the region (see Table 1 ), $a=\%$ of the total high forests of Greece, $b=$ of the total high forests and forest lands of Greece, $c=\%$ of the total area of Greece, $\sqrt{ }=$ only natural stands in the Region 7.

in Greece (Figure 8) for the different Regions (Figure 9) are presented in Table 1 , whereas the total high forests and others forest lands are shown in Table 2. The data presented are from the national forest inventory of forest in Greece (1992). The new/latest forest inventory data are not yet available (under processing). There may be changes in the coverage of the forests in the range (over country) of $\pm 5 \%$ - $10 \%$ depending on various factors (e.g. wild fires, afforestation of abandoned agricultural lands in the mountains, land use changes, human activities).

The natural distribution of the main forest species is highly dependent on geographical (latitude, longitude, altitude), climatic, hydrological, geological and pedological (soil) factors [2] [5] [6]. For example, cold adapted species (e.g. beech, spruce, scotch pine, hybrid fir) are generally grown on the high mountains of north and central Greece (Figure 1, Figure 5, Figure 10) whereas species adapted to hot and dry environments (e.g. Pinus halepensis, P. brutia, most 


\section{Map of Regions and Regional Unities of Greece}

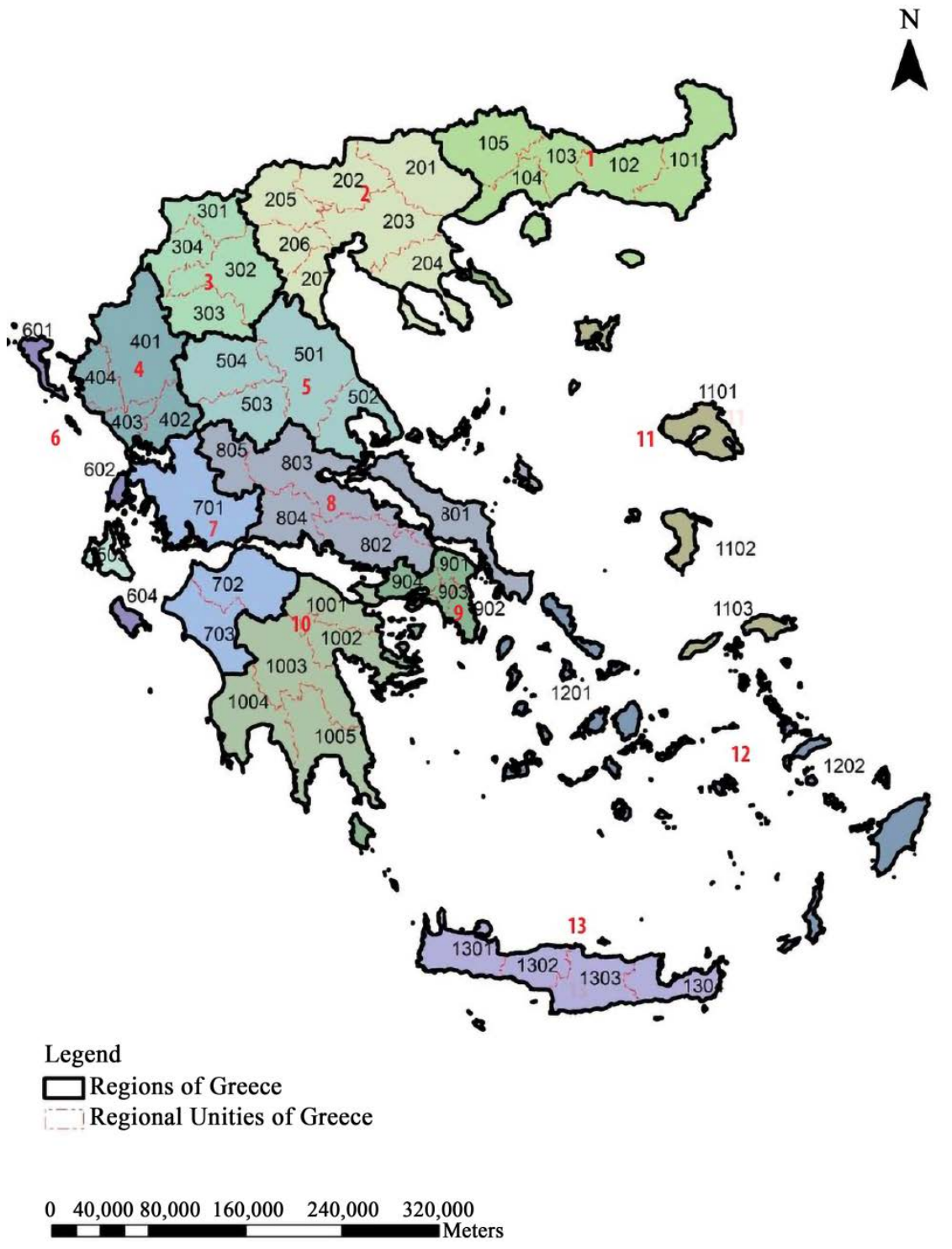

Figure 9. Geographic Regions of Greece (source: Hellenic Statistical Authority (ELSTAT) $2020[4]$.

of evergreen broadleaves) are mainly grown on the lowlands of south-east and some islands where hot and dry summers are common (Figure 4, Figure 5). A very characteristic example of adaptation is the black pine (Pinus nigra) (Figure 10(a)) which forms the best and most productive stands on soils derived from flysch (Pindos Mt.) (Figure 2, Figure 5, Figure 10).

\section{Stocks of Organic Carbon in Forest Soils in Greece}

The amounts of carbon (C) stocks in forest soils vary according to climatic and ecological zones [7]. In general, the amounts are high in cold climates and are reduced as temperature increase. In the forest areas of cold regions, the amount of $\mathrm{C}$ in soils can reach $80 \%$ of the total C in plants and soils. In temperate zones, 
Table 2. Coverage (ha/\%) of the total high forests and other forest lands in Greece for the different Regions of Greece (source: Ministry of Agriculture 1992) [3].

\begin{tabular}{|c|c|c|c|c|c|c|}
\hline $\begin{array}{l}\text { REGION } \\
\text { CODE }\end{array}$ & $\begin{array}{c}\text { REGION } \\
\text { AREA (Ha) }\end{array}$ & $\begin{array}{l}\text { TOTAL HIGH } \\
\text { FORESTS } \\
(\mathrm{Ha} / \%)\end{array}$ & $\begin{array}{c}\text { EVERGREEN } \\
\text { BROADLEAVES } \\
(\mathrm{Ha} / \%)\end{array}$ & $\begin{array}{c}\text { GRAZELANDS } \\
(\mathrm{Ha} / \%)\end{array}$ & $\begin{array}{l}\text { INFERTILE/ } \\
\text { ROCKY- } \\
\text { BARELANDS } \\
(\mathrm{Ha} / \%)\end{array}$ & $\begin{array}{c}\text { TOTAL HIGH } \\
\text { FORESTS AND } \\
\text { FOREST LANDS } \\
\quad((\mathrm{Ha} / \%)\end{array}$ \\
\hline I & II & III & IV & V & VI & VII \\
\hline \multirow{2}{*}{1} & \multirow{2}{*}{$1,415,700$} & $646,489.0$ & $198,506.0$ & 78,482 & 7442 & $930,919.0$ \\
\hline & & $45.67(\%)^{\star}$ & 14.02 & 5.54 & 0.53 & $65.76^{\star}$ \\
\hline \multirow{2}{*}{2} & \multirow{2}{*}{$1,914,100$} & $512,969.0$ & 390,163 & 135,344 & 15,113 & $1,053,589.0$ \\
\hline & & 26.80 & 20.38 & 7.07 & 0.79 & 55.04 \\
\hline \multirow{2}{*}{3} & \multirow{2}{*}{945,100} & $275,421.0$ & $142,400.0$ & 173,633 & 9360 & $600,814.0$ \\
\hline & & 29.14 & 15.07 & 18.37 & 0.99 & 63.57 \\
\hline \multirow{2}{*}{4} & \multirow{2}{*}{$1,403,700$} & $300,100.0$ & $313,344.0$ & 138,963 & 13,327 & $765,734.0$ \\
\hline & & 21.38 & 22.32 & 9.90 & 0.95 & 54.55 \\
\hline \multirow{2}{*}{5} & \multirow{2}{*}{920,300} & $277,245.0$ & $246,110.0$ & 190,734 & 41,231 & $755,320.0$ \\
\hline & & 30.13 & 26.74 & 20.73 & 4.48 & 82.07 \\
\hline \multirow{2}{*}{6} & \multirow{2}{*}{230,700} & $21,877.0$ & $85,215.0$ & 18,500 & 1867 & $127,459.0$ \\
\hline & & 9.48 & 36.94 & 8.02 & 0.81 & 55.25 \\
\hline \multirow{2}{*}{7} & \multirow{2}{*}{$1,135,000$} & $285,350.0$ & $267,935.0$ & 88,260 & 24,041 & $665,586.0$ \\
\hline & & 25.14 & 23.61 & 7.78 & 2.12 & 58.64 \\
\hline \multirow{2}{*}{8} & \multirow{2}{*}{$1,554,900$} & $512,619.0$ & 478,908 & 145,125 & 25,640 & $1,162,292.0$ \\
\hline & & 32.97 & 30.80 & 9.33 & 1.65 & 74.75 \\
\hline \multirow{2}{*}{9} & \multirow{2}{*}{380,800} & $74,064.0$ & 90,652 & 26,743 & 2393 & $193,852.0$ \\
\hline & & 19.45 & 23.81 & 7.02 & 0.63 & 50.91 \\
\hline \multirow{2}{*}{10} & \multirow{2}{*}{$1,549,000$} & $251,640.0$ & $503,937.0$ & 100,525 & 9474 & $865,576.0$ \\
\hline & & 16.25 & 32.53 & 6.49 & 0.61 & 55.88 \\
\hline \multirow{2}{*}{11} & \multirow{2}{*}{383,600} & $78,129.0$ & $118,344.0$ & 46,479 & 5561 & $248,513.0$ \\
\hline & & 20.37 & 30.85 & 12.12 & 1.45 & 64.78 \\
\hline \multirow{2}{*}{12} & \multirow{2}{*}{528,600} & $70,213.0$ & $118,970.0$ & 116,848 & 18,953 & $324,984.0$ \\
\hline & & 13.28 & 22.51 & 22.11 & 3.59 & 61.48 \\
\hline \multirow{2}{*}{13} & \multirow{2}{*}{833,600} & $43,127.0$ & $199,398.0$ & 167,584 & 7165 & $417,274.0$ \\
\hline & & 5.17 & 23.92 & 20.10 & 0.86 & 50.06 \\
\hline \multirow{3}{*}{ TOTAL } & \multirow{3}{*}{$13,195,100$} & $3,349,243$ & $3,153,882$ & $1,427,220$ & 181,567 & $8,111,912$ \\
\hline & & $41.29^{\mathrm{a}}$ & $38.88^{\mathrm{a}}$ & $17.59^{\mathrm{a}}$ & $2.24^{\mathrm{a}}$ & $61.48^{b}$ \\
\hline & & $25.38^{b}$ & $23.90^{\mathrm{b}}$ & $10.82^{b}$ & $1.38^{\mathrm{b}}$ & \\
\hline
\end{tabular}

$*=\%$ cover of the total region area, $a=\%$ of the total forests and other forest lands (over country), $b=\%$ cover of the total country area.

the respective $\mathrm{C}$ amount is about $60 \%$ and in tropical forests about $50 \%$. Table 3 shows the average $\mathrm{C}$ stock in the most important ecological regions in the world.

In Greece, the calculation of organic $\mathrm{C}$ stocks was carried out in the framework of the National project "Classification, Mapping and Evaluation of the Lands of Greece". The project lasted 22 years (1978-2000) and it was implemented by the Ministry of Agriculture in cooperation with the Institute of Mediterranean Forest Ecosystems [8]. The calculation was based on data derived from 2260 soil pits scattered all over the country. The soil depth for which the $\mathrm{C}$ 


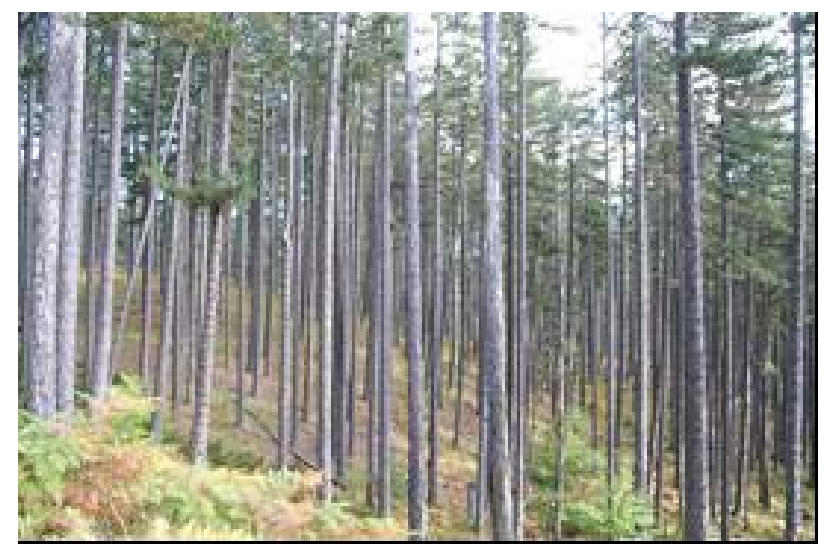

(a)

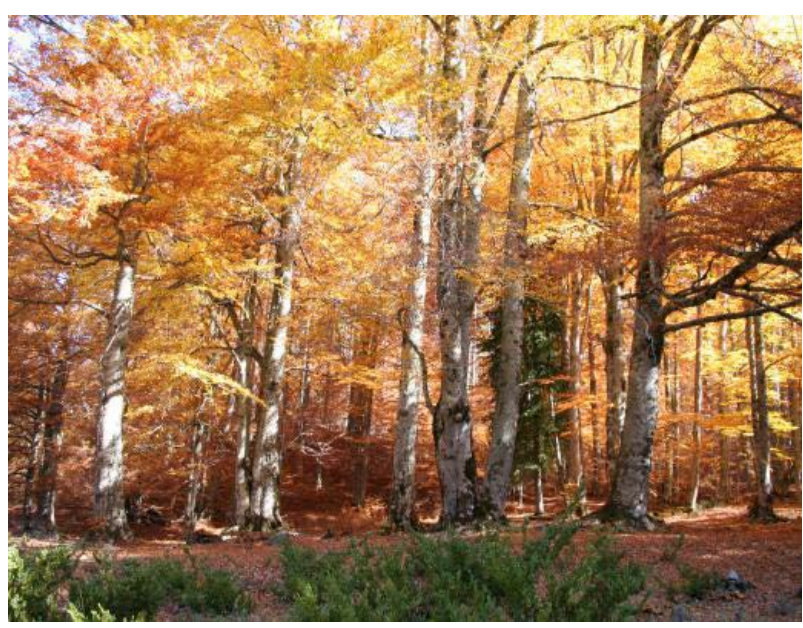

(b)

Figure 10. Black pine (Pinus nigra) (a) and beech (Fagus silvatica) (b) in Pindos Mt. (Greece) (photo: I. Tzatzanis).

Table 3. Estimation of the average carbon stocks (tones.ha ${ }^{-1}$ ) in plant biomass and soils in forests of different ecological regions [7].

\begin{tabular}{ccc}
\hline & Plants & Soils \\
\hline Tropical forests & 157 & 122 \\
Forests in temperate zone & 96 & 122 \\
Forests in cold regions & 53 & 300 \\
\hline
\end{tabular}

was calculated reached the upper limit of the bedrock (parent material). The volume of the coarse material (stones and gravel) was subtracted from the total soil volume. The litter layer (L) was not taken into account for the calculations. The calculations were based on $\mathrm{C}$ concentrations, soil volume and bulk density. The summarized results for $\mathrm{C}$ stocks are presented in Table 4 [8] and were processed according to the forest vegetation zones described below.

A forest vegetation zone is the spatial distribution of the various forest tree species according to their demands in temperature and moisture. In Greece, four major vegetation zones have been defined [6]: 
Table 4. Stocks of organic C in forest soils and graze lands in Greece.

\begin{tabular}{cccc}
\hline \multicolumn{3}{c}{ Vegetation Organic C } & \\
\hline Zone & tons $\cdot \mathbf{h a}^{-1}$ & $\mathrm{CV}(\%)^{*}$ & Total (tons $\times \mathbf{1 0}^{6}$ ) \\
\hline Forests & & \\
Evergreen broadleaves & 72.0 & 54 & 40.4 \\
Aleppo pine + Calabrian pine & 72.9 & 54 & 30.4 \\
Deciduous oaks & 80.3 & 48 & 62.0 \\
Fir & 114.0 & 52 & 31.1 \\
Black pines & 115.0 & 51 & 15.1 \\
Beech & 120.0 & 52 & 36.0 \\
Pseudoalpine & $\underline{\text { Pastures }}$ & & 21.8 \\
\hline
\end{tabular}

${ }^{*} \mathrm{CV}(\%)$ : Coefficient of variation.

1) The maquis zone (or the zone of evergreen broadleaves). It is found at an altitude of $0-1300 \mathrm{~m}$. The main vegetation consists of Aleppo pine (Pinus halepensis), Calabrian pine (Pinus brutia) and evergreen broadleaves (Quercus coccifera, Pistacia spp., Olea oleaster Arbutus spp., etc.). It occupies the $47.5 \%$ of the country area.

2) The zone of deciduous oaks. It is found at an altitude of $200-300 \mathrm{~m}$ and can reach $1000-1300 \mathrm{~m}$. The species are Quercus frainetto, Quercus ithaburensis, Quercus cerris, Quercus pubescens, Quercus robur and others.It occupies the $39.2 \%$ of the country area.

3) The fir (Abies) zone with the subzones of beech (Fagus spp.), Scots pine (Pinus sylvestris), and black pine (Pinus nigra). Its altitude ranges between 700 and $1800 \mathrm{~m}$. It is the most important forest zone and covers the $11.8 \%$ of the country area.

4) Pseudoalpine zone. It is found at an altitude of more than $1600 \mathrm{~m}$ and occupies the $1.5 \%$ of the country area. In this zone, the species Juniperus nana, Juniperus foeditissima, Festuca sp. Astragalus sp. Sesleria sp. and other species adapted to this zone can be found.

In Greece, the mountain forests (fir, beech, black pine) contain the highest average amount of carbon in soils (more than 100 tons per hectare).However, the soils of deciduous oaks due to the large cover area, have the highest total amount of carbon, approximately 60 million tons (in total).

\section{Forest Biodiversity}

Biodiversity is the whole set of genes, species, and ecosystems in an area and refers to: 1) gene differences between populations or individuals of the same species; 2) species diversity refers to the variety of plants, animals, and microorganisms in a system; and 3) the diversity of ecosystems refers to the diversity of different ecosystems [9] [10]. The protection of forest biodiversity is an important 
action for the management of ecosystems because is the essential factor for the conservation of the ecosystem and provides support for many forest goods and services. In forests, biodiversity allows species to evolve and adapt dynamically to the changing environment, to maintain the potential for reproduction and health of trees in order to meet human needs in goods and services, and to support the functions of the ecosystems. Assessment and monitoring of forest biodiversity are considered as important activities aiming at guiding the sustainable management of forests [9] [10] [11] [12].

The Mediterranean Basin is a biodiversity hotspot and is one of the most remarkable areas of the planet for its great biological diversity and its landscapes [13]. It is essentially established as a transitional zone, ranging from the temperate climate of South Europe to the warm/dry regions of Africa where various types of ecosystems are found to co-exist [14]. Forest biodiversity in Greece is one of the richest (in terms of species richness and biodiversity quality) in $\mathrm{Eu}$ rope. This is partly due to the influence of diverse climate and micro-climatic types varying from semi-arid type of Southeastern Crete to cold wet continental type in North-Western Greece (Figure 4 \& Figure 5). Geographic diversity for most of the native species is high due to geographic/geomorphological/geological/ pedological factors (e.g. latitude, exposure, altitude, geology, soils) that have strongly affected biological and genetic processes(reproductive biology, pollination, gene flow, hybridization, isolation, adaptation, heterozygosity, population effective number) and consequently genetic diversity (intrepopulation/intra-population). However, conservation measures should be taken for the threatened and marginal populations (e.g. Fagus spp., Fraxinus angustifolia, Acer platanoides, Sorbus spp., Taxus baccata, Juniperus spp.) through in situ (keep viable population effective numbers) and ex situ conservation (gene conservation).

The importance of forests as biodiversity components has been widely recognized [10] [15] [16]. There is a strong legal protection status for all forested areas and special efforts have been made in recent years for the identification and conservation of their biodiversity values. The number of plant taxa (species and subspecies) of the very rich flora in Greece is estimated to 6500 (5750 species); $15.1 \%-17.6 \%$ at species and $17.7 \%-20.9 \%$ at taxa level are endemic [17]. More than 50,000 animal species (the majority are described insects), there are already 25,000 are described out of which about $25 \%$ are endemic, more than 2000 species of fungi and 25 groups of habitat types (according to the CORINE classification and Directive 92/43/of the European Union).

Since Greece started creating protected areas, administration has been carried out by the Forest Service through its Forest District Offices (governmental bodies under the Ministry of Environment and Climatic Change). Decisions are made centrally and management practices include strict protection. Although Law 1650/1986 granted more power to Ministry of Environment, Planning and Public Works, which is the main operator of forest policy development in the protected areas created after 1986, the actual management of all protected areas, 
created before 1986, still remains within Forest District Offices. Currently, 28 protected areas with Management Bodies were designated (Law 3044/2002) [18] [19]. The implementation of the Habitat Directive in 1992 was a turning point in national forest policy followed by changes in administration, in the role of conservation authorities, new funding possibilities and broader involvement in decision-making and forest policy. The creation of Natura 2000 framework serves multi-purpose objectives under the frame of sustainable forest management in the designated sites [5] [20]. The International conventions ratified by the State and related to Biodiversity have to do with the adoption of the international goals and the implementation of a defined framework of protection of Biodiversity. Apart from the National Parks and other protected areas [12] of particular importance are important protected areas for the Nature and Biodiversity such as (https://ypen.gov.gr/, 2015) [18]: 1) The wetlands of International Importance of the Ramsar Convention; 2) The Monuments of the World Inheritance (UNESCO); 3) The Biosphere Reserves (UNESCO, Human and Biosphere); 4) The Special Protected Areas (Convention of Barcelona); 5) The Biogenetic Reserves (Council of Europe); 6) The Areas that have been awarded the Eurodiploma (Council of Europe); and 7) Paris Agreement.

Furthermore, the following future challenges for biodiversity policy are very important: a) coding and revising/improving the legislation for the conservation of biodiversity; b) strengthening the public administration for the implementation and the coordination of political measures and legislation for biodiversity; c) development of forest maps and a new forest inventory (urgently needed), completion of soil and land use maps for Greece, and d) institutional safeguarding of Natura 2000 areas.

\section{Conservation of Forests Genetic Resources-Genetic and Epigenetic Variation}

Greece ranks third and fourth of 103 key biodiversity areas in Europe and Mediterranean area, respectively [21]. Genetic diversity is the fundamental basis of biodiversity at the species and ecosystems levels according [10] [22]. Numerous studies in Greece show high levels of genetic diversity for Prunus avium [23] [24] [25], Pinus halepensis [10] [26], Fraxinus spp. [27] [28] [29], Fagus sylvatica cluster species [30], etc. Forest populations in Greece present very high polymorphism and genetic differentiation according to a comparison study with European forests which was conducted by Aravanopoulos et al. (2019) [31]. "Marginal or peripheral" populations of forest tree species are those which exist in the edge of their geographic distributions where populations have often persisted over long periods of geological time and experienced a complex evolutionary history [26]. Many forest tree species are considered as marginal populations in Greece due to the geomorphology of the country and geographic isolation of many islands. Conservation of forest genetic resources should be the primary step of any conservation strategy aiming at ensuring long-term persistence of 
species and habitats [10] [12] [30]. Traditionally there are two main strategies considering conservation: the "in situ" and the "ex situ". The "in situ" strategy conserves species in their natural environment while the "ex situ" conserves populations and individuals as copies outside of their natural habitat. Considering the biotic and abiotic pressures that Greece faces under the climatic changes - which are already apparent-isolated and marginal forest tree populations must be conserved in order to secure their future existence and survival [10] [12] [27] [30].

Nowadays a serious debate of how epigenetic mechanisms trigger and evolve in the adaptation for forest tree species has begun. Epigenetics is defined as the mechanism that alters gene expression without changes in the DNA sequence and those alterations are transmitted to the next generation [32]. Methylation of DNA, modification of histones, structural changes in chromatins and non-coding RNA are mechanisms of epigenetics. For example, in Languncularia racemosa (mangrove tree), a study showed that in contrasting habitats exhibited different morphological traits (fresh water and nutrient supply vs salt march) and epigenetic variation was greater than genetic variation (within and between populations) based on analysis of DNA sequences and methylation patterns [33]. Lastly the combination of genetic and epigenetic variation can give us a holistic approach for conservation and adaptation of forest tree species [32] [34] under the climatic changes that already occurring.

\section{Effects of Climate Change on Forest Biodiversity}

As expected, the climatic change has already affected the Mediterranean region, with prolonged periods of aridity, severe storms-more frequent than before-floods, extreme heat waves and more mega-fires. The aftermath of these rapid and severe changes of climatic conditions within the next 100 years, will affect the well-being and overall existence of the Mediterranean forests [35].

Climate change is a global threat that has already had an observed impact on biodiversity, and forest ecosystems. The contrasting plant functional types competing for water, characterize the Mediterranean ecosystems [36]. These plants are sensitive to temperature rise and any changes regarding water availability [37]. They have already sustained numerous climatic changes, adjusting themselves in various ways (by changing physiological procedures, adapting their genotypes or even by immigration) [38]. However, further temperature increase and/or water deprivation is expected to cause biodiversity loss and significant changes of indigenous-natural vegetation in the (not so far) future [39].

Many studies foresee habitat reduction due to climate change though, with different habitat loss rates [40]. The habitat loss [41] and seed production [42] will be affected by climate change, with direct effects on plant communities. The most sensitive forests in the Mediterranean are those extended to the southern limits of the Mediterranean basin (e.g. beech, spruce, Scots pine). Changes in atmospheric $\mathrm{CO}_{2}$ concentration (possibly reaching $600 \mathrm{ppm}$ at the end of the 
century [43] will have severe impacts on forest tree populations, by affecting productivity, water use efficiency [44] [45] and belowground carbon storage.

Apart from the plant species that configure the biodiversity of Greek forests there is also a rich forest fauna comprised of many vertebrate and invertebrate taxa. Within them, there are several alien and/or invasive species that take advantage of the health condition of forest plants in order to exploit without facing sufficient quantities of chemical defense mechanisms. In Greece, the impact of climate change (extended droughts, elevated atmospheric $\mathrm{CO}_{2}$ ) will affect the physiology of forest trees and cause changes in biotic interactions among trees, herbivory and fungi in several ways [46] [47] [48]. For example, increased levels of $\mathrm{CO}_{2}$ can affect the susceptibility to herbivores which are oriented towards to their nutritious tissues. Following these lines it is expected that the drought that accompanies many climate changes will render susceptible many plants among them the Greek fir (Abies cephalonica) and European beech [30]. Moreover, the elevated atmospheric $\mathrm{CO}_{2}$ together with the increased growth of the tree is expected to reduce the resistance of $A$. cephalonica and make this species attractive to herbivores. Also the belowground environment is important for those organisms that need humid environment (e.g. fungi) which is found in the root system of trees [47].

In a meta-analysis of all relevant bibliographic databases and searches by using as keywords the main forest species such as Abies, Acer, Quercus, Fagus, Pinus and other genera, Jactel [48] and colleagues analyzed the effect of drought on the damage of primary and secondary forest pests and pathogens and using Hedge's $d$ as a measure. They found that the overall impact of climate change to forests is quite complicated and the salient effects could be:

1) Primary wood pests and pathogens are expected to cause lower damage to forest trees affected from drought; 2) Primary pests and pathogens consuming the foliage of forest trees are expected to cause significantly more feeding damage; 3) Secondary pests and pathogens are expected to cause more damage to forest species in agreement with the host stress hypothesis; 4) The geographic and host plant ranges of many pests are expected to increase in search of suitable feeding, ovipositing, and mate encountering substrate; 5) Since different feeding guilds and various specialization types of pests and pathogens are expected to be differentially affected by drought, Greece is a temperate-subtropical country which will increase the number of pests and pathogens; 6) Since many biotopes are being destroyed as a result of human economic activities, previous results are difficult to be predicted with certainty; 7) Native species inhabiting occasionally urban sites are expected to decrease as a result of the pollution and insecticide spraying against arthropods; 8) As a result of introductions and spreading of pests in the forest trees, forest biodiversity is expected to significantly decrease; 9) The globally observed insect decline is expected to affect Greek entomofauna; 10) The increase of the numbers of alien and invasive insects as a result of migration or inadvertent introductions and establishment is the most important 
effect of climate change and is expected to affect the fauna in Greece and may reduce biodiversity.

Studies are currently carried out in order to gain a better insight in the various effects of climate change in the estimation of growth rate of various forest plant taxa such as conifers. Important studies involve carbon (C) and oxygen (O) stable isotopes in tree-ring analysis on the premises that ${ }^{13} \mathrm{C}$ enrichment of a-cellulose in tree-rings is expected to show if the growth reduction of conifers is the result of defoliation or climate change or both. Also, the isotopic composition of tree-ring cellulose, in terms of ${ }^{18} \mathrm{O}$, reflects the isotopic signature of source water, leaf water, and fractionation when photosynthetic sugars are biosynthesized.

\section{Forest Management, Multiple Uses, Protection and Conservation of Forests of Greece}

Forests in Greece have been managed sustainably over a long period of time until now [5] [30] [49]. The management of the forests of the main forest species in Greece, their multiple functions and uses, protection and conservation in the face of climate change are synoptically presented in Table 5. They are an essential resource for local communities in terms of both wood (e.g. timber, firewood, wood biomass) and non-wood products (e.g. fruits and seeds, mushrooms, snails, medicines, herbal plants, recreation, hunting, grazing, resin, honey) [50] [51] (Table 5). Also highly important is the functional role of the forest ecosystems of Greece (Table 5). The main ecosystem functions have long been recognised as following: soil conservation, water balance, carbon sequestration (above and below ground), wild life maintenance, climate change mitigation, and biodiversity support [10] [16] [52] [53] [54] [55].

In general, forest management applied in Greece is sustainable, following the forest management plans approved by the Forest Service. The average growing stock is estimated to be $62 \mathrm{~m}^{3} /$ ha and around $70 \%$ of the harvested wood is used as firewood [3]. Clear cuts and coppicing are mostly applied in non-state forest lands (municipal, church owned, other private lands). The coppiced forestsaveraging $48 \%-50 \%$ of the total forests-are still managed by this system, but recently there has been political and societal pressure to partly convert those into seedling ones. A large part ( $\approx 60 \%)$ of the forests and forested lands have been included in the NATURA 2000 network [5] [20].

\section{Adaptive Forest Management and Silviculture-Conservation Measures}

One of the adaptation strategies concerning forest vegetation is the migration to regions with more beneficial climatic conditions. However, not all trees can do this, because there are species which cannot respond to the requirements needed for establishing new communities, in other areas [56]. Tinner and Lotter (2006) [57] calculated that species needing a migration transition of $100 \mathrm{~km}$, will need 
Table 5. Forests of Greece, management and their multiple functions and uses, protection and conservation in the face of climate change.

\begin{tabular}{|c|c|c|c|c|c|c|}
\hline \multirow{2}{*}{$\begin{array}{l}\text { Forest type } \\
\text { (tree species) }\end{array}$} & \multirow{2}{*}{$\begin{array}{l}\text { Management } \\
\text { type/silvicultural } \\
\text { methods/regeneration }\end{array}$} & \multicolumn{2}{|c|}{ Products and uses } & \multirow{2}{*}{$\begin{array}{l}\text { Risks and } \\
\text { pests }\end{array}$} & \multirow{2}{*}{$\begin{array}{l}\text { Protection measures/ } \\
\text { biodiversity conservation/ } \\
\text { genetic diversity }\end{array}$} & \multirow{2}{*}{$\begin{array}{l}\text { Actions to face } \\
\text { climate change }\end{array}$} \\
\hline & & $\begin{array}{l}\text { Products } \\
\text { (wood and } \\
\text { non-wood) }\end{array}$ & $\begin{array}{l}\text { Functions/ } \\
\text { services }\end{array}$ & & & \\
\hline $\begin{array}{l}\text { FIR }(\text { Abies } \\
\text { cephalonica, } \times \\
\text { Abies borissi } \\
\text { regis, } \text { A. alba) }\end{array}$ & $\begin{array}{l}\text { Seedling } \\
\text { stands/unevenaged, all } \\
\text { age classes/shelterwood } \\
\text { regeneration (single } \\
\text { tree selection, small } \\
\text { group selection) } \\
\text { (rotation period } 80 \text { - } \\
120 \text { years) }\end{array}$ & $\begin{array}{l}\text { round wood } \\
\text { (sawn timber), } \\
\text { power poles, } \\
\text { paper pulp, } \\
\text { honey } \\
\text { production }\end{array}$ & $\begin{array}{l}\text { soil protection, } \\
\text { water balance, } \\
\text { bee feeding, } \\
\text { wild life, } \\
\text { landscape } \\
\text { enhancement }\end{array}$ & $\begin{array}{l}\text { wild fires, } \\
\text { landslides, } \\
\text { overgrazing, } \\
\text { bark beetles, } \\
\text { roor-rot fungi, } \\
\text { climate change, } \\
\text { illegal cuttings }\end{array}$ & $\begin{array}{l}\text { wild fire preventive actions, control } \\
\text { grazing, in situ conservation, } \\
\text { maintain viable population sizes in } \\
\text { isolated/remnant } \\
\text { populations/natural hybrids Abies } \\
\text { cephalonica } \times \text { A. alba }(\times \text { Abies } \\
\text { borissi regis), conserve } \\
\text { inter/intra-population diversity (in } \\
\text { situ) }\end{array}$ & $\begin{array}{l}\text { enhance mixture } \\
\text { with broadleaves } \\
\text { (e.g. oak, beech), } \\
\text { remove died } \\
\text { trees/sanitary } \\
\text { actions, }\end{array}$ \\
\hline $\begin{array}{l}\text { NORWAY } \\
\text { SPRUCE (Picea } \\
\text { abies) }\end{array}$ & $\begin{array}{l}\text { Seedling stands/ } \\
\text { evenaged, uneven aged, } \\
\text { all age classes/intense } \\
\text { shelterwood in groups } \\
\text { (large or small) } \\
\text { regeneration (rotation } \\
\text { period } 80 \text { - } 120 \text { years) }\end{array}$ & $\begin{array}{l}\text { round wood } \\
\text { (sawn timber), } \\
\text { power poles, } \\
\text { paper pulp }\end{array}$ & $\begin{array}{l}\text { soil protection, } \\
\text { water balance, } \\
\text { wild life, } \\
\text { landscape } \\
\text { enhancement }\end{array}$ & $\begin{array}{l}\text { bark beetles, } \\
\text { roor-rot fungi, } \\
\text { climate change }\end{array}$ & $\begin{array}{l}\text { in situ conservation (the south } \\
\text { limit of spruce distribution in } \\
\text { the Balkans), maintain viable } \\
\text { population sizes in isolated/ } \\
\text { remnant populations }\end{array}$ & $\begin{array}{l}\text { enhance mixture } \\
\text { with broadleaves } \\
\text { or conifers(e.g. } \\
\text { beech, scots pine), } \\
\text { remove died trees/ } \\
\text { sanitary actions, }\end{array}$ \\
\hline $\begin{array}{l}\text { SCOTS PINE } \\
\text { (Pinus } \\
\text { sylvestris) }\end{array}$ & $\begin{array}{l}\text { Seedling stands/ } \\
\text { evenaged, unevenaged } \\
\text { stands/shelterwood } \\
\text { regeneration (in large } \\
\text { area, in strips) (rotation } \\
\text { period } 80 \text { - } 100 \text { years, } \\
\text { for power poles 50) }\end{array}$ & $\begin{array}{l}\text { round wood } \\
\text { (sawn timber), } \\
\text { fencing poles, } \\
\text { power poles, } \\
\text { paper pulp, }\end{array}$ & $\begin{array}{l}\text { soil protection, } \\
\text { water balance, } \\
\text { wild life, } \\
\text { biodiversity } \\
\text { conservation, } \\
\text { landscape } \\
\text { enhancement }\end{array}$ & $\begin{array}{l}\text { overgrazing, } \\
\text { roor-rot fungi, } \\
\text { illegal cuttings, } \\
\text { climate change }\end{array}$ & $\begin{array}{l}\text { control grazing, in situ } \\
\text { conservation (the south limit of } \\
\text { scots pinedistribution in the } \\
\text { Balkans), maintain viable } \\
\text { population sizes in isolated } \\
\text { populations }\end{array}$ & $\begin{array}{l}\text { enhance mixture } \\
\text { with broadleaves } \\
\text { (e.g. beech, oak), } \\
\text { remove died trees } \\
\text { (sanitary actions) }\end{array}$ \\
\hline $\begin{array}{l}\text { BLACK PINE } \\
\text { (Pinus nigra) }\end{array}$ & $\begin{array}{l}\text { Seedling stands/ } \\
\text { evenaged, unevenaged } \\
\text { stands/shelterwood } \\
\text { regeneration (crown } \\
\text { closure } 0.4 \text { - } 0.6, \text { in } \\
\text { large area or in strips) } \\
\text { (rotation period } 80 \text { - } \\
120 \text { years) }\end{array}$ & $\begin{array}{l}\text { round wood } \\
\text { (sawn timber), } \\
\text { power poles, } \\
\text { paper pulp }\end{array}$ & $\begin{array}{l}\text { soil protection, } \\
\text { water balance, } \\
\text { wild life, } \\
\text { biodiversity } \\
\text { conservation, } \\
\text { landscape } \\
\text { enhancement }\end{array}$ & $\begin{array}{l}\text { Wild fires, } \\
\text { overgrazing, } \\
\text { roor-rot fungi, } \\
\text { illegal cuttings, } \\
\text { climate change }\end{array}$ & $\begin{array}{l}\text { control grazing, in situ } \\
\text { conservation (the south limit of } \\
\text { black pinedistribution in the } \\
\text { Balkans), maintain viable } \\
\text { population sizes in isolated } \\
\text { populations }\end{array}$ & $\begin{array}{l}\text { enhance mixture } \\
\text { with broadleaves } \\
\text { (e.g. beech, oak), } \\
\text { remove died trees } \\
\text { (sanitary actions) }\end{array}$ \\
\hline $\begin{array}{l}\text { BOSNIAN PINE } \\
\text { (Pinus } \\
\text { heldreichii) }\end{array}$ & $\begin{array}{l}\text { Seedling stands/ } \\
\text { evenaged, unevenaged } \\
\text { stands/shelterwood } \\
\text { regeneration (crown } \\
\text { closure } 0.4-0.6, \text { in } \\
\text { small groups or in } \\
\text { strips) (rotation period } \\
80 \text { - } 120 \text { years) }\end{array}$ & $\begin{array}{l}\text { round wood } \\
\text { (sawn timber), } \\
\text { power poles, } \\
\text { paper pulp, } \\
\text { wood craft, } \\
\text { wooden barrels }\end{array}$ & $\begin{array}{l}\text { soil protection, } \\
\text { water balance, } \\
\text { wild life, } \\
\text { biodiversity } \\
\text { conservation, } \\
\text { landscape } \\
\text { enhancement }\end{array}$ & $\begin{array}{l}\text { overgrazing, } \\
\text { illegal cuttings, } \\
\text { climate change }\end{array}$ & $\begin{array}{l}\text { control grazing, in situ } \\
\text { conservation (the south limit of } \\
\text { Bosnian pinedistribution in the } \\
\text { Balkans), maintain viable } \\
\text { population sizes in isolated } \\
\text { populations }\end{array}$ & $\begin{array}{l}\text { maintain viable } \\
\text { population sizes } \\
\text { in isolated } \\
\text { populations, } \\
\text { maintain intra- } \\
\text { and } \\
\text { inter-population } \\
\text { genetic diversity }\end{array}$ \\
\hline $\begin{array}{l}\text { HALLEPO \& } \\
\text { CALABRIAN } \\
\text { PINE (Pinus } \\
\text { halepensis \& } P . \\
\text { brutia) }\end{array}$ & $\begin{array}{l}\text { Seedling stands/ } \\
\text { evenaged, unevenaged } \\
\text { stands/clear cuts with } \\
\text { standards (seed trees) } \\
\text { or shelterwood } \\
\text { regeneration (in large } \\
\text { areas) (rotation period } \\
50 \text { - } 100 \text { years }\end{array}$ & $\begin{array}{l}\text { round wood } \\
\text { (sawn timber), } \\
\text { fencing poles, } \\
\text { fuelwood, resin } \\
\text { production, } \\
\text { honey } \\
\text { production, } \\
\text { firewood, boat } \\
\text { construction }\end{array}$ & $\begin{array}{l}\text { soil protection, } \\
\text { wild life, } \\
\text { biodiversity } \\
\text { conservation, } \\
\text { landscape } \\
\text { enhancement }\end{array}$ & $\begin{array}{l}\text { wild fires, } \\
\text { overgrazing, } \\
\text { wood-rot fungi } \\
\text { (due to } \\
\text { wounding for } \\
\text { resin), illegal } \\
\text { cuttings, } \\
\text { climate change }\end{array}$ & $\begin{array}{l}\text { Fire prevention, remove surplus } \\
\text { biomass, control grazing, in situ } \\
\text { conservation (inter/intra } \\
\text { population diversity, natural } \\
\text { hybridization), biodiversity } \\
\text { conservation (understory woody } \\
\text { species, aromatic/medicinal } \\
\text { herbs), }\end{array}$ & $\begin{array}{l}\text { enhance mixture } \\
\text { with broadleaves } \\
\text { (e.g. Quercus } \\
\text { pubescens, Q. ilex, } \\
\text { Fraxinus ornus) }\end{array}$ \\
\hline
\end{tabular}




\section{Continued}

\begin{tabular}{|c|c|c|c|c|}
\hline $\begin{array}{l}\text { Pinus pinea } \\
\text { (stone pine) }\end{array}$ & $\begin{array}{l}\text { Seedling stands/ } \\
\text { evenaged, unevenaged } \\
\text { stands/intense fellings } \\
\text { with standards (seed } \\
\text { trees), crown closure } \\
0.3-0.4 \text {, rotation } \\
\text { period } 80 \text { - } 100 \text { years }\end{array}$ & $\begin{array}{l}\text { round wood } \\
\text { (sawn timber), } \\
\text { fuelwood, pine } \\
\text { nuts, } \\
\text { wood/resin } \\
\text { extracts }\end{array}$ & $\begin{array}{l}\text { soil protection, } \\
\text { wild life, } \\
\text { biodiversity } \\
\text { conservation, } \\
\text { landscape } \\
\text { enhancement }\end{array}$ & $\begin{array}{l}\text { wild fires, } \\
\text { overgrazing, } \\
\text { llegal cuttings, } \\
\text { climate change }\end{array}$ \\
\hline $\begin{array}{l}\text { COMMON } \\
\text { CYPRESS } \\
\text { (Cupressus } \\
\text { sempervirens) }\end{array}$ & $\begin{array}{l}\text { Seedling stands (natural } \\
\text { regeneration in native } \\
\text { stands) (rotation period } \\
60 \text { - } 100 \text { years) }\end{array}$ & $\begin{array}{l}\text { round wood } \\
\text { (sawn timber), } \\
\text { power poles, } \\
\text { boat } \\
\text { construction }\end{array}$ & $\begin{array}{l}\text { soil protection, } \\
\text { landscape } \\
\text { improvement, } \\
\text { wind } \\
\text { protection, } \\
\text { cultural value }\end{array}$ & $\begin{array}{l}\text { overgrazing, } \\
\text { bark beetles, } \\
\text { bark canker } \\
\text { (Seiridium } \\
\text { spp.), climate } \\
\text { change }\end{array}$ \\
\hline
\end{tabular}

Fire prevention, remove surplus enhance mixture

biomass, control grazing, in situ with broadleaves stands/intense fellings (sawn timber), wild life,

conservation (natural/ (e.g. Quercus trees), crown closure nuts, naturalised populations), pubescens, Q. ilex, biodiversity conservation Fraxinus ornus) (understory woody species, aromatic/medicinal herbs),

wild fire preventive actions, control grazing, in situ conservation (e.g. natural populations in islands), maintain islands), maintain viable population sizes in isolated/remnant populations

in situ conservation

(e.g. natural populations in viable population sizes in isolated/
JUNIPER Seedling stands, most

(Juniperus spp.) stands out of management fencing poles,

berries for

liqueur production soil protection, grazing, illegal control grazing, in situ wild life cuttings, crown conservation (inter/intra conservation, biodiversity enhancement, landscape pathogens (e.g. Phomopsis spp.) chang enhancement

soil protection, overgrazing, control grazing, in situ (Fagus sylvatica stands, coppice converted (sawn timber), cluster species to seedling stands/ fuel wood, -Fagus sylvatica evenaged, uneven aged, industrial subsp. sylvatica, irregular stands/ wood, energy F. sylvatica shelterwood regeneration wood, subsp. orientalis) (in large reg. area or small groups) (rotation period 80 - 130 years

BIRCH Seedling stands/ (Betula pendula) evenaged, unevenaged stands/shelterwood in large areas, rotation period 60 - 100 years

round wood (sawn timber), plywood, fuelwood, wild life, biodiversity

(n)
pine) wild life, illegal cuttings, limit of birch distribution in the biodiversity conservation, landscape

climate change Balkans), maintain viable population sizes in remnant populations, maintain intra- and inter-popul. genetic diversity

in situ conservation (interpopulation diversity, threatened species/populatio ns)

maintain most of genetic diversity, maintain viable population sizes in isolated/remnant populations, enhance mixture (e.g. oak, fir, pine)

soil protection, roor-rot fungi, in situ conservation (the south maintain viable enhancement population sizes in isolated/remnant populations, isolated/remnant populations, enhance mixture enhance mixture (e.g. scots pine) (e.g. scots pine) to to face climate change face climate change

CHESTNUT Coppice stands round wood soil protection, Phytophthora

(Castanea vera) Coppice stands (sawn timber), water balance, spp. and converted to high forest poles, fuelwood, wild life, (rotation period 15 - 60 nuts, years)

biodiverity

enhancement attacks, Cryptonectria parasitica

control grazing, in situ conservation (inter/intra population diversity), maintain viable population sizes in remnant populations, conserve roor-rot fungi, ofold grown stands and trees, illegal cuttings, enhance mixture (e.g. oak) to climate change face climate change control grazing, in situ conservation (inter/intrapopulation diversity), maintain viable population sizes in remnant populations, enhance mixture (e.g. oak) to face climate change 


\section{Continued}

\begin{tabular}{|c|c|c|c|c|c|c|}
\hline $\begin{array}{l}\text { OAK (Quercus } \\
\text { spp.) }\end{array}$ & $\begin{array}{l}\text { Seedling stands, Coppice } \\
\text { stands, Coppice stands } \\
\text { converted to high } \\
\text { forest/evenaged, } \\
\text { unevenaged, irregular } \\
\text { stands with old grown } \\
\text { standards/clear cuts with } \\
\text { standards, shelterwood } \\
\text { regeneration (in large } \\
\text { areas-removal of } 10 \% \text { - } \\
20 \% \text { of trees/coppice } \\
\text { stems, keep crown } \\
\text { closure } 0,8 \text { ) (rotation } \\
\text { period: coppiced stands } \\
25 \text { years, seedling stands } \\
80 \text { - } 120 \text { years) }\end{array}$ & $\begin{array}{l}\text { rarely round } \\
\text { wood (sawn } \\
\text { timber for floor } \\
\text { parkets), mainly } \\
\text { fuelwood, } \\
\text { animal feeding } \\
\text { (leaves/accorns), } \\
\text { mushrrom } \\
\text { production, }\end{array}$ & $\begin{array}{l}\text { soil protection, } \\
\text { water balance, } \\
\text { wild life, } \\
\text { biodiverity } \\
\text { enhancement }\end{array}$ & $\begin{array}{l}\text { overgrazing, } \\
\text { oak decline, } \\
\text { defoliating } \\
\text { insects, } \\
\text { roor-rot fungi, } \\
\text { climate change }\end{array}$ & $\begin{array}{l}\text { control grazing, in situ } \\
\text { conservation (endemic } \\
\text { species-Q. euboica, inter/intra } \\
\text { population diversity, natural } \\
\text { hybridization), maintain viable } \\
\text { population sizes in remnant } \\
\text { populations (e.g. } Q \text {. } \\
\text { inhaburensis), enhance mixture } \\
\text { (e.g. oak, fir, pine) to face } \\
\text { climate change }\end{array}$ & $\begin{array}{l}\text { control grazing, in } \\
\text { situ conservation } \\
\text { (inter/intra } \\
\text { population } \\
\text { diversity), } \\
\text { maintain viable } \\
\text { population sizes } \\
\text { in remnant/old } \\
\text { age populations, } \\
\text { enhance mixture } \\
\text { eto face climate } \\
\text { change }\end{array}$ \\
\hline $\begin{array}{l}\text { MAPLE (Acer } \\
\text { spp.) }\end{array}$ & $\begin{array}{l}\text { Seedling stands/ } \\
\text { evenaged, unevenaged } \\
\text { stands/shelterwood in } \\
\text { groups, rotation period } \\
60 \text { - } 100 \text { years (mostly } \\
\text { out of management) }\end{array}$ & $\begin{array}{l}\text { round wood } \\
\text { (sawn timber) }\end{array}$ & $\begin{array}{l}\text { soil protection, } \\
\text { wild life } \\
\text { protection, } \\
\text { biodiversity } \\
\text { enhancement, }\end{array}$ & $\begin{array}{l}\text { overgrazing, } \\
\text { illegal cuttings, } \\
\text { climate change }\end{array}$ & $\begin{array}{l}\text { Forest inventory/mapping, legal } \\
\text { actions/measures, in situ } \\
\text { conservation (e.g. threatened } \\
\text { species/populations), } \\
\text { maintain genetic diversity } \\
\text { (inter/intra population diversity, } \\
\text { maintain viable population sizes } \\
\text { in remnant populations) to face } \\
\text { climate change }\end{array}$ & $\begin{array}{l}\text { Conserve/enhance } \\
\text { mixture different } \\
\text { species-e.g. beech, } \\
\text { oak), sanitary } \\
\text { actions, maintain } \\
\text { genetic diversity } \\
\text { (inter/intra } \\
\text { population } \\
\text { diversity, maintain } \\
\text { viable population } \\
\text { sizes in } \\
\text { isolated/remnant } \\
\text { populations) }\end{array}$ \\
\hline $\begin{array}{l}\text { RIVERINE/WE } \\
\text { TLANDFORES } \\
\text { TS (Platanus } \\
\text { orientalis, } \\
\text { Populus alba, P. } \\
\text { nigra, Salix spp., } \\
\text { Ulmus spp., } \\
\text { Fraxinus } \\
\text { angustifolia) }\end{array}$ & $\begin{array}{l}\text { Seedling stands or } \\
\text { coppiced stands /mainly } \\
\text { natural regeneration(by } \\
\text { seed or sprouts) (mostly } \\
\text { out of management) } \\
\text { (rotation period } 50 \text { - } \\
100 \text { years) }\end{array}$ & $\begin{array}{l}\text { round wood } \\
\text { (sawn timber), } \\
\text { poles, plywood, } \\
\text { wood boards, } \\
\text { paper pulp, } \\
\text { cellulose/fibers, } \\
\text { energy wood, } \\
\text { bio-compost, } \\
\text { honey } \\
\text { production, } \\
\text { agroforestry use }\end{array}$ & $\begin{array}{l}\text { soil protection, } \\
\text { phyto- } \\
\text { remediation, } \\
\text { wild life } \\
\text { protection, } \\
\text { biodiversity } \\
\text { enhancement, } \\
\text { landscape } \\
\text { enhancement }\end{array}$ & $\begin{array}{l}\text { deforestation, } \\
\text { illegal cuttings, } \\
\text { insects } \\
\text { (defoliators), } \\
\text { pathogens } \\
\text { (root-rot/wood } \\
\text { rot fungi), } \\
\text { water table } \\
\text { changes, } \\
\text { climate change }\end{array}$ & $\begin{array}{l}\text { Forest inventory/mapping, legal } \\
\text { actions/measures, in situ } \\
\text { conservation (e.g. threatened } \\
\text { species/populations), } \\
\text { maintain genetic diversity } \\
\text { (inter/intra population diversity, } \\
\text { maintain viable population sizes } \\
\text { in remnant populations) to face } \\
\text { climate change }\end{array}$ & $\begin{array}{l}\text { Conserve/enhance } \\
\text { mixture different } \\
\text { species), sanitary } \\
\text { actions, extend } \\
\text { carbon storage, } \\
\text { maintain genetic } \\
\text { diversity } \\
\text { (inter/intra } \\
\text { population } \\
\text { diversity, } \\
\text { maintain viable } \\
\text { population sizes } \\
\text { in remnant } \\
\text { populations) }\end{array}$ \\
\hline $\begin{array}{l}\text { PLANTATIONS } \\
\text { (hybrid poplars, } \\
\text { native } \\
\text { poplars/willows, } \\
\text { ash, paulownia, } \\
\text { eucalypts) }\end{array}$ & $\begin{array}{l}\text { replanting or } \\
\text { coppicing/evenaged, } \\
\text { unevenaged } \\
\text { stands/rotation period } \\
10 \text { - } 30 \text { years }\end{array}$ & $\begin{array}{l}\text { round wood } \\
\text { (sawn timber), } \\
\text { poles, plywood, } \\
\text { wood boards, } \\
\text { paper pulp, } \\
\text { cellulose/fibers, } \\
\text { energy wood, } \\
\text { bio-compost, } \\
\text { honey } \\
\text { production, } \\
\text { agroforestry use }\end{array}$ & $\begin{array}{l}\text { soil protection, } \\
\text { phyto- } \\
\text { remediation, } \\
\text { wild life } \\
\text { protection, } \\
\text { biodiversity } \\
\text { enhancement, } \\
\text { landscape } \\
\text { enhancement }\end{array}$ & $\begin{array}{l}\text { grazing, insects } \\
\text { (defoliators, } \\
\text { bark beetles, } \\
\text { wood } \\
\text { borers)pathoge } \\
\text { ns (root-rot, } \\
\text { rust fungi, } \\
\text { wood rot } \\
\text { fungi), climate } \\
\text { change }\end{array}$ & $\begin{array}{l}\text { control grazing (at least the first } \\
10 \text { years), ex situ conservation } \\
\text { (e.g. selected genotypes/clones, } \\
\text { threatened } \\
\text { populations/provenances), } \\
\text { enhance mixture (e.g. different } \\
\text { provenances, different clones) to } \\
\text { face climate change }\end{array}$ & $\begin{array}{l}\text { enhance mixture } \\
\text { (use different } \\
\text { provenances/ } \\
\text { clones), sanitary } \\
\text { actions, extend } \\
\text { carbon storage }\end{array}$ \\
\hline
\end{tabular}


250 - 1000 years in order to accomplish it, when the climatic change is to happen much faster: according to A1B scenario, the average temperature increase velocity is going to be $42 \mathrm{Km} / 100$ years, in some regions reaching $100-1000 \mathrm{Km} / 100$ years [58]. It is a fact that spatial climatic changes will occur with different regional rates, higher at lowlands and lower on mountainous regions [59] [60] and different migration rates are expected among species depending on their reproductive biology. During the past, there were migrations to cooler areas and also altitudinal upward shifts of vegetation. Bussoti et al. (2014) [60] states that a natural migration pattern from south to north and from low to higher altitudes will be followed by the tree species in concern. Lenoir et al. (2008) [61] reported certain upward shift rates in 171 forest plant species in France of about $30 \mathrm{~m}$ per decade when warming and elevation lapse rates were much higher (about $75 \mathrm{~m}$ per decade).

In general, evergreen species appear to be slower to adaptation in changing environments [62]. Bussoti et al. (2014) [60] found that evergreen Mediterranean species are not likely to respond to a fast climatic change by evolutionary adaptation but probably survive by migration. It is expected that evergreen tree species will occupy in the future xeric region which are now covered by deciduous oaks, while mountain conifers and temperate deciduous species will be limited to their southern extension ranges. Less frost injuries of trees [63] and increased winter photosynthesis [64] are expected during future warmer Mediterranean winters [65]. Sensitive to cold species will be favored over the existing cold-tolerant ones, resulting in a competition of species and affecting the structure of the forests, their population dynamics and possibly causing their conversion to shrublands [65].

Based on the above conclusions we can admit that Mediterranean mountains are considered to be highly vulnerable to climatic changes [66] [67]. It is unfortunately predicted that the mountain of the Mediterranean region will suffer interannual variability, precipitation decrease, excess warming and consequently loss of plant species, more intensely than other mountains [68] predict that the vegetation of the Mediterranean mountains is bound to undergone great changes. Xerophyllous vegetation will considerably increase and will cover low mountain areas together with perennial sclerophyllous species, while moderate tolerant to water availability vegetation will notably decrease. Other changes have to do with the forest vegetation of higher altitudes which will be up-shifted, the expansion of semi-arid forests, the depletion of broadleaf forests (e.g. beech, oak) and last but not least, the reduction in the expansion of cold gymnosperm forests (e.g. spruce, Scots pine, Bosnian pine [69].

Greece, as part of the Mediterranean Basin, is exposed to many risks and hazards due to the combined effect of high temperatures and reduced precipitation in areas already coping with water scarcity [18] [19] [52] [70]. Furthermore, land use changes and land use conflicts make this problem more complex. It is therefore quite urgent to adapt forest management to the changing climate in order to 
enable the conservation of healthy, productive forests, which provide people with goods and services. Integrating climate change into forest management requires an understanding of ecological response and the vulnerability of key tree species and their forest ecosystems. Although a clear view of the future climate and forests is not yet available, it is critical to begin developing and implementing adaptation strategies now, well in advance of climate change (already happens) impacts on the forests. It should be pointed out that the impacts of climate change push the forest ecosystems to higher altitudes and/or being replaced by others. Thus, it is crucial to adapt silvicultural systems (e.g. convert coppiced stands into high forests, increase seed production and genetic diversity) in order to mitigate climate change and conserve, utilize as much as possible genetic diversity and enhance in situ conservation (particularly of mature and old grown forests). However, as it is known, genetics/genetic diversity is a dynamic biological process and therefore it is not possible to maintain the whole of it (whenever is recorded) [10]. Losses will be inevitably occurring during the time but it is important and profitable to maintain high effective population numbers for the keystone species (e.g. beech, fir, oak, pine) in order to conserve a rich biodiversity and high biodiversity quality [2] [10] [27].

Climate change mitigation and adaption is one of the main targets identified in the strategy for sustainable development launched by Ministry of Environment, Energy and Climate Change (MEECC) in 2002. Greece ratified the Kyoto Protocol in 2002 (Law 3017/2002) and adopted a National Programme ensuring its commitment by a decision of the Council of Ministers (DCM5/2003). By the Law 3017/2002, the Ministry for the Energy, Environment, and Climate Change is designated as the governmental body responsible for the coordination of all other competent ministries and possibly any other public and/or private entities, for (a) the implementation of the provisions of the Kyoto Protocol and (b) the formulation and monitoring of the National Programme for achieving the national targets set under the Kyoto Protocol [18] [19] and recently, Paris Agreement.

The Strategic Plan of Rural Development 2007-2013 identified the priorities of Greece for the period 2007-2013. The National Strategy was implemented by the Program of Rural Development 2007-2013 (Hellenic Ministry of Rural Development and Food, November 2007), whose priorities are set in order to adapt agriculture and forestry to climate change. The priorities related to forestry are outlined: a) operation of the system for the protection of forests from fires and other natural hazards, control of harmful pests and diseases that will affect forests and their productivity, and b) development of an information system regarding forests. Some important actions regarding to forest protection and adaptation to climate change have included [14] [15]: 1) Construction of new roads in order to improve forest road networks; 2) Construction of water supply centers (water pipes, water tanks, etc.) and related works to improve the network of water provision for fire suppression; 3) Removing/reducing dry biomass close 
to the ground or along forest roads and other areas of high fire risk; 4) Tending, thinning and pruning works in coniferous forests (particularly in pine stands) in order to remove part of the flammable biomass, improve accessibility and stand quality; 5) Construction and improvement of permanent forest fire surveillance systems.

In addition to the measures above, actions have been taken in order to increase and restore forest areas [18] [19] [52]: 1) reforestation plans (using native species and local provenances) for the restoration of fire destroyed forest areas; 2) logging and removal of burnt trees (removal is not recommended in steep slopes-e.g. $>30 \%$ inclination-for at least 3 years); 3) restoration works (reforestation, soil erosion prevention, etc.) and planting of less flammable species (e.g. Cupressus sempervirens and native broadleaves replacing $P$. halepensis or $P$. brutia); 4) soil erosion preventive works in small erosion gullies using wood, stone, concrete, wire, etc.; 5) watershed management in order to minimize soil degradation and maximize water storing and construction of small dams for collection of rain water; 6) drainage works to prevent landslides in sensitive geological substrata (e.g. Pindos Mountain, N. Evia, W. Peloponnisos).

Furthermore, in the context of the First Afforestation of Agricultural and Non-Agricultural Soils, 36,612 ha had to be afforested in the period 2004-2012 [18] [19]. Also, in the Program of Rural Development 2007-2013, actions concerning the reduction of coppice forests and conversion into high forests and the increase, renewal, improvement, replacement and enhancement of stoking volume with the introduction of native species in degraded stands and bare lands, were also included. Currently, Greece is addressing the issue of climate change through the National Action Plan, as a sequence of the adaptation of the Directive 2009/28/EC (Article 4) and has submitted to EU/DG-ENERGY, a first version of its national action plan in 2009 and a second version followed in 2011. According to this National Action Plan, a set of measures was taken into consideration. The three starting points of these measures were: 1) the establishment of a new Ministry in which climate change is a top priority; 2) the formal acknowledgment of the priority given to achievement of the 2020 targets set (Directive 2009/28/EC and international commitments of the country for the protection of the environment); and 3) the adoption by the Parliament (Law L3851/2010) in which national targets for Renewable Energy sources were specified $20 \%$ of the total energy consumption (mandatory level of $18 \%$ set by the Directive 2009/28/EC) [18] [19]. Finally, the new Rural Development Program (2014-2020), which is currently under the final implementation phase, will take into consideration the forests (production and protection) and forest-related European and National legal obligations.

To summarize, conservation measures and strategies for protecting forest biodiversity in Greece are highly important issues. Global climate change and pollution may cause change in the present distribution of important species (e.g. beech, oak, spruce, fir, pine) (e.g. movement upwards to higher altitudes) and 
replacing parts of the beech forest area by other species (e.g. oak, fir, pine) [71]. Furthermore, some important evolutionary forces and actions should be considered when sustainable forest management and adaptive silviculture are applied in order to face climate change [72] [30]: 1) evolutionary dynamics of forest trees; 2) maintenance of viable population effective numbers; 3 ) threats to a population or a species; 4) sustainable silviculture; and 5) conservation (in situ/ex situ) of forest genetic resources.

\section{Forests of Greece, Forest Policy and Forest Economy-Future Prospects}

A main characteristic of Greece is that most of the forest area is located in areas with high mountains and slopes where the harvesting procedures, in most of the times are extremely difficult. In addition, the production and often the quality of the produced wood for many managerial and ecological reasons is limited (e.g. a lot of knots, trunk defects, small sizes). Koulelis (2009) [73] placed Greece among low-productivity EU counties. Wood removals, at national level are influenced by a number of negative factors such as organizational issues (i.e. harvesting procedures), lack of funding on forest management plans, vague ownership of forest land, problems with forest law compliance, governance issues, bureaucracy, illegal logging or generally inefficient national forest policy. As it was expected the forest products trade deficit in Greece is a characteristic of the national forest sector over time [74]. Moreover, Greece has always had a trade balance deficit, but it became unprecedented during the euro years. Koulelis (2009) found that from an annual average of 25 billion in euro trade deficit in the pre-euro period, it became 33 billion euro in the euro years (2002-2014), reaching annual values of 44 billion euro during the three years before the crisis (2006-2008). Part of the trade balance deficit also concerns the forest products trade deficit which has continuously increased over the years. More specifically, after 2001 when in the rest of the EU the forest products trade deficit was decreasing, in Greece increased rapidly, reaching \$1.2 billion in 2008 compared to $\$ 293$ million in the 1980s and \$778 million in the 1990s [74]. Conclusively, the national forest sector entered the financial crisis in a relatively weak position and the adverse effects of the fall in demand have been felt throughout the sector with severe structural and employment consequences. After 2008 and during the financial crisis, roundwood apparent consumption followed an important decline. The biggest drop began in 2008, with an annual decline of $36.6 \%$. An important recovery was observed until 2012 , followed by a severe decline. The total decrease of this particular consumption was measured $20.6 \%$. Over the double roundwood decline, a decline in the sawnwood consumption was observed as well. The consumers reduced the demand for sawnwood by $50.8 \%$ during the crisis. Moreover, the consumption of wood-based panels dropped by $83.6 \%$ (Ibid). It is important to underline here that sawnwood and panels are common for individual use or use by smaller firms or bigger and as well are associated to the 
building and constructions sector. In Greece, which has historically played an important developmental role in terms of supporting the economy of small productive or commercial firms, has strengthened the domestic timber production of small sawn mills, keeping the levels of unemployment in the sector low, and finally supported local communities. Simultaneously, is reported that overall, during the three-year period 2008-2011, the industry lost $7.9 \%$ of its value, equivalent to 1.44 bn $€$ and lost $37 \%$ of the total workforce, equivalent to about 200.000 employment positions [75]. Small-scale industries and larger enterprises were closed or transformed to commercial. In 2008, around 7.000 people were employed in the forest sector in Greece, whereas in 2011, this number decreased to less than 4.000. By contrast, the consumption per capita of fuelwood seems to have an increased trend during the crisis. Increasing oil prices in combination with the current economic crisis of the economic system is motive enough for many households in Greece to satisfy their energy consumption needs by exploiting Renewable Energy Sources (RES) [76] [77]. In more detail, Koulelis (2016) [78] found an increased consumption per capita of fuelwood totally by $17.2 \%$.

Priorities such as knowledge transfer and innovation in agriculture, forestry, and rural areas, but also the competitiveness of the agricultural sector and sustainable forestry, are now under negotiation following the updated National Forest Strategy (NFS) which has been legislated with the Ministerial Decision No. 170195/758 of 28 November 2018 [79]. The NFS determines the principles of forest policy in Greece for the next twenty years, emphasizing on the model of Mediterranean forestry and on sustainable forest management. The ultimate goal for forestry is to improve life quality of the urban population and preserve the environment through the sustainable exploitation of forest resources, with an anticipated contribution of $1 \%$ to the national GDP. Until now, as Tsiaras et al. (2020) [80] reported, in the ranking of the EU countries based on their contribution of forest sector to the Gross Domestic Product, Greece is found in the third place from the bottom of the classification between 26 countries, as the forest sector contributes to the country's GDP only a minimal percentage of $0.05 \%[81]$.

It's more than obvious, that the structural problems of the forest sector in Greece cannot be addressed easily, but requires a rather thorough reassessment of policies, a more wide-ranging vision and the adoption of the bio-economy energy industry development, in the policy planning process. On the other hand, an increased domestic production of timber products (from both, natural forests and plantations) and an efficient marketing would gradually reduce imports [77]. Moreover, the establishment of a new highly organized structure of small-scale industrial plantations [77] [82], could make domestic roundwood products more competitive.

Finally, actions such as sustaining existing raw material resources, enhance forest plantations establishment and afforesttion of abandoned agricultural and 
also investing in production infrastructures are highly important [77] [83]. Developing a qualified and cost-competitive labor force, creating an attractive investment climate, and providing economic stimulus measures in the primary wood processing and furniture industry and NWFP (Non-Wood Forest Products) [50] [51] are also important sectors. The suggested actions aim to the restructuring and strengthening the connection of forest businesses with partners from urban areas, and tentatively from abroad.

\section{Conclusions and Future Challenges}

- A general overview on the forests, forest management and forest biodiversity of Greece are briefly summarized.

- The distribution of the main forest species and their ecosystems in the Geographic regions of Greece is presented in a tabular form.

- Their multiple functions and uses, their management type/regime, their risks and threats, protection and conservation measures are also synoptically described.

- Furthermore, adaptive forest management and silviculture as well as management of genetic diversity in order to face climate change are also analysed.

- Research priority areas on biodiversity and challenges for biodiversity research and related policy in Greece have been summarized.

- Greece has been trying to adapt to new International, European and National conditions and policies. New biodiversity legislation has been adopted since 2012 including for the first time forest-specific measures on species and habitats' protection.

- The new Rural Development Program (2014-2020), which is currently on the final phase of implementation, will take into consideration the forest itself and forest-related European and National legal obligations.

- In the future, it is critical to identify the linkage between biodiversity, climate change and ecosystem services.

- Promotion landscape multi-functionality (farmland and forests), which contribute to multiple sustainable goals, benefiting both people and biodiversity.

- Conduction of forest policy, socio-economic and ecological studies that use mixed data to extract relationships between biodiversity, ecosystem services and production.

\section{Acknowledgements}

The authors express their thanks to Mr. Ioannis Tzatzanis (Forest Manager) for providing photos of Pinus nigra and Fagus silvatica (Pindos Mt.).

\section{Conflicts of Interest}

The authors declare no conflicts of interest regarding the publication of this paper. 


\section{References}

[1] Nakos, G. (1991) Classification, Mapping and Evaluation of Soils in Greece. Soil Map of Greece, 67.

[2] Mavromatis, G. (1980) The Bioclimate of Greece. Correlations of Climate and Natural Vegetation-Bioclimatic Maps. Dasiki Erevna, Vol. 1, Appendix, Athens.

[3] Ministry of Agriculture (1992) First National Inventory of Greece, General Secretariat of Forests and Natural Environment. Independent Edition.

[4] Hellenic Statistical Authority (ELSTAT) (2020). https://www.statistics.gr/documents/20181/1515741/GreeceInFigures_2020Q4

[5] Dafis, S., Papastergiadou, E., Georgiou, K., Babalonas, D., Georgiadis, T., Papageorgiou, M., Lazaridou, T. and Tsiaousi, V. (1997) Directive 92/43/E.C. Works Biotopes in Greece: Network NATURA 2000. Gouladri Museum of Natural History-Hellenic Center of Biotopes and Wetlands, 932. (In Hellenic)

[6] Dafis, S. (1973) Classification of Forest Vegetation in Greece. Scientific Annual of the Agricultural and Forestry School. Volume IE, Issue B. Aristotle University of Thessaloniki, Thessaloniki.

[7] Lal, R. (2005) Forest Soils and Carbon Sequestration. Forest Ecology and Management, 220, 242-258. https://doi.org/10.1016/j.foreco.2005.08.015

[8] Nakos, G., Michopoulos, P., Economou, A. and Kaoukis, K. (2010) Assessment of the Organic Carbon Stocks in Greek Forest Soils. Greek Ministry of Rural Development and Food, General Secretariat of Forests and Natural Environment, National Agricultural Research Foundation-Institute of Mediterranean Forest Ecosystems, Athens.

[9] Larson, T.B. (2001) Biodiversity Evaluation Tools for European Forests. Ecological Bulletins No. 50. Wallin \& Dalholm, Lund, 233.

[10] Spanos, K.A., Feest, A., Petrakis, P. and Daskalakou, E. (2010) Silent Points on the Assessment and Monitoring of Biodiversity. Bioremediation, Biodiversity and Bioavailability, 4, 1-7.

[11] Skouteri, A., Daskalakou, E., Kourakli, P., Spanos, K. and Petrakis, P. (2013) Biodiversity and Greek Forest Policy. The Meeting of the Working Group 1 "Forest-Related Policy Targets and Measures", COST ACTION FP 1207, Orchestrating Forest-Related Policy Analysis in Europe (ORCHESTRA), Prague, 12-13 November 2013, 13.

[12] Spanos, K.A., Gaitanis, D., Skouteri, A., Petrakis, P. and Meliadis, I. (2018) Implementation of Forest Policy in Greece in Relation to Biodiversity and Climate Change. Open Journal of Ecology, 8, 174-191.

https://doi.org/10.4236/oje.2018.83012

[13] Mittermeier, R.A., Gil, P.R., Hoffman, M., Pilgrim, J., Brooks, T., Mittermeier, C. and Saligmann, P.A. (2004) Hotspots Revisited: Earth's Biologically Richest and Most Endangered Terrestrial Ecoregions.

[14] Doblas-Miranda, E., Alonso, R., Arnan, X., Bermejo, V., Brotons, L., De las Heras, J., Retana, J., et al. (2017) A Review of the Combination among Global Change Factors in Forests, Shrublands and Pastures of the Mediterranean Region: Beyond Drought Effects. Global and Planetary Change, 148, 42-54.

https://doi.org/10.1016/j.gloplacha.2016.11.012

[15] Petrakis, P.V. (2008) Current Insect Extinctions. In: Mass Extinction, Springer, Berlin, 195-249. https://doi.org/10.1007/978-3-540-75916-4_15

[16] Kotsiras, K., Kokkoris, I.P., Arne Strid, A. and Dimopoulos, P. (2020) Integrating 
Plant Diversity Data into Mapping and Assessment of Ecosystem and Their Services (MAES) Implementation in Greece: Woodland and Forest Pilot. Forests, 11, 956. https://doi.org/10.3390/f11090956

[17] Dimopoulos, P., Raus, T., Bergmeier, E., Constantinidis, Th., Iatrou, G., Kokkini, S., Strid, A. and Tzanoudakis, D. (2013) Checklist of the Vascular Plants of Greece, Hellenic Botanical Society (HBS) and the Botanic Garden and Botanical Museum Berlin-Dahlem (BGBM).

[18] http://www.ypeka.gr/Default.aspx?tabid=237

[19] http://www.minagric.gr

[20] Tsianou, M.A., Mazaris, A.D., Kallimanis, A.S., Deligioridi, P.S.K., Apostolopoulou, E. and Pantis, J.D. (2013) Identifying the Criteria Underlying the Political Decision for the Prioritization of the Greek Nature 2000 Conservation Network. Biological Conservation, 166, 103-110. https://doi.org/10.1016/j.biocon.2013.06.021

[21] Dernegi, D. (2010) Ecosystem Profile: Mediterranean Basin Biodiversity Hotspot. Critical Ecosystem Partnership Fund.

[22] Aravanopoulos, F. (2011) Genetic Monitoring in Natural Perennial Plant Populations. Botany, 89, 75-81. https://doi.org/10.1139/b10-087

[23] Magri, D., Vendramin, G.G., Comps, B., Dupanloup, I., Geburek, T., Gömöry, D., Latałowa, M., Litt, T., Paule, L. and Roure, J.M. (2006) A New Scenario for the Quaternary History of European Beech Populations: Palaeobotanical Evidence and Genetic Consequences. New Phytologist, 171, 199-221. https://doi.org/10.1111/j.1469-8137.2006.01740.x

[24] Ganopoulos, I., Aravanopoulos, F.A., Argiriou, A., Kalivas, A. and Tsaftaris, A. (2011) Is the Genetic Diversity of Small Scattered Forest Tree Populations at the Southern Limits of Their Range More Prone to Stochastic Events? A Wild Cherry Case Study by Microsatellite-Based Markers. Tree Genetics \& Genomes, 7, 1299-1313. https://doi.org/10.1007/s11295-011-0414-2

[25] Avramidou, E., Ganopoulos, I.V. and Aravanopoulos, F.A. (2010) DNA Fingerprinting of Elite Greek Wild Cherry (Prunus avium L.) Genotypes Using Microsatellite Markers. Forestry, 83, 527-533. https://doi.org/10.1093/forestry/cpq035

[26] Fady, B., Aravanopoulos, F.A., Alizoti, P., Mátyás, C., von Wühlisch, G., Westergren, M., Zlatanov, T., et al. (2016) Evolution-Based Approach Needed for the Conservation and Silviculture of Peripheral Forest Tree Populations. Forest Ecology and Management, 375, 66-75. https://doi.org/10.1016/j.foreco.2016.05.015

[27] Fraxigen (2005) Ash Species in Europe: Biological Characteristics and Practical Guidelines for Sustainable Use. Oxford Forestry Institute, University of Oxford, Oxford, $128 \mathrm{p}$.

[28] Papi, R.M., Spanos, K.A. and Kyriakidis, D.A. (2012) Genetic Variation Fraxinus angustifolia Natural Populations in Greece Based on Nuclear Ad Chloroplast Microsatellite Markers. European Journal of Forest Research, 131, 1151-1161. https://doi.org/10.1007/s10342-011-0586-1

[29] Spanos, K.A. and Gaitanis, D. (2020) Wood Biomass Production from a 10-Year Old Plantation of Fraxinus angustifolia Vahl in Greece. Modern Environmental Science and Engineering, 6, 573-582.

[30] Spanos, K.A. (2010): (Ed.) Beech Genetic Resources for Sustainable Forestry in Europe. Proceedings of the Workshop and MC Meeting of the COST Action E52. "Evaluation of Beech Genetic Resources for Sustainable Forestry", Thessaloniki, 5-7 May 2009, $133 \mathrm{p}$.

[31] Aravanopoulos, F.A., Alizoti, P.G., Farsakoglou, A.-M., Malliarou, E., Avramidou, 
E.V. and Tourvas, N. (2019) State of Biodiversity and Forest Genetic Resources in Greece in Relation to Conservation. In: Forests of Southeast Europe under a Changing Climate, Springer, Berlin, 73-83.

https://doi.org/10.1007/978-3-319-95267-3_6

[32] Avramidou, E.V., Doulis, A.G. and Aravanopoulos, F.A. (2015) Determination of Epigenetic Inheritance, Genetic Inheritance, and Estimation of Genome DNA Methylation in a Full-Sib Family of Cupressus sempervirens L. Gene, 562, 180-187. https://doi.org/10.1016/j.gene.2015.02.068

[33] Lira-Medeiros, C.F., Parisod, C., Fernandes, R.A., Mata, C.S., Cardoso, M.A. and Ferreira, P.C.G. (2010) Epigenetic Variation in Mangrove Plants Occurring in Contrasting Natural Environment. PLoS ONE, 5, e10326.

https://doi.org/10.1371/journal.pone.0010326

[34] Rey, O., Eizaguirre, C., Angers, B., Baltazar-Soares, M., Sagonas, K., Prunier, J.G. and Blanchet, S. (2020) Linking Epigenetics and Biological Conservation: Towards a Conservation Epigenetics Perspective. Functional Ecology, 34, 414-427. https://doi.org/10.1111/1365-2435.13429

[35] Regato, P. and Korakaki, E. (2010) The Mediterranean Forests against Global Climate Change. Publications: WWF Greece, 106.

[36] Montaldo, N., Corona, R. and Albertson, J. (2016) The Climate Change Impact on the Water Balance and Use Efficiency of Two Contrasting Water Limited Mediterranean Ecosystems in Sardinia. EGUGA, EPSC2016-8647.

[37] Guiot, J. and Cramer, W. (2016) Climate Change: The 2015 Paris Agreement Thresholds and Mediterranean Basin Ecosystems. Science, 354, 465-468.

https://doi.org/10.1126/science.aah5015

[38] Thompson, I., Mackey, B., McNulty, S. and Mosseler, A. (2009) Forest Resilience, Biodiversity, and Climate Change. Secretariat of the Convention on Biological Diversity, Montreal, Technical Series No. 43, 1-67.

[39] Keenan, T., Maria Serra, J., Lloret, F., Ninyerola, M. and Sabate, S. (2011) Predicting the Future of Forests in the Mediterranean under Climate Change, with Niche- and Process-Based Models: $\mathrm{CO}_{2}$ Matters. Global Change Biology, 17, 565-579. https://doi.org/10.1111/j.1365-2486.2010.02254.x

[40] Beltrán, B.J., Franklin, J., Syphard, A.D., Regan, H.M., Flint, L.E. and Flint, A.L. (2014) Effects of Climate Change and Urban Development on the Distribution and Conservation of Vegetation in a Mediterranean Type Ecosystem. International Journal of Geographical Information Science, 28, 1561-1589. https://doi.org/10.1080/13658816.2013.846472

[41] Scalercio, S. (2009) On top of a Mediterranean Massif: Climate Change and Conservation of Orophilous Moths at the Southern Boundary of Their Range (Lepidoptera: Macroheterocera). European Journal of Entomology, 106, 231-239. https://doi.org/10.14411/eje.2009.031

[42] Sánchez-Humanes, B. and Espelta, J.M. (2011) Increased Drought Reduces Acorn Production in Quercus Ilex Coppices: Thinning Mitigates This Effect But Only in the Short Term. Forestry, 84, 73-82. https://doi.org/10.1093/forestry/cpq045

[43] Christensen, J.H., Hewitson, B., Busuioc, A., Chen, A., Gao, X., Held, R. and Dethloff, K. (2007) Regional Climate Projections. In: Climate Change, 2007: The Physical Science Basis. Contribution of Working Group I to the Fourth Assessment Report of the Intergovernmental Panel on Climate Change, University Press, Cambridge, Chapter 11, 847-940.

[44] Rickebusch, S., Thuiller, W., Hickler, T., Araujo, M.B., Sykes, M.T., Schweiger, O. 
and Lafourcade, B. (2008) Incorporating the Effects of Changes in Vegetation Functioning and $\mathrm{CO}_{2}$ on Water Availability in Plant Habitat Models. Biology Letters, 4, 556-559. https://doi.org/10.1098/rsbl.2008.0105

[45] Higgins, S.I. and Scheiter, S. (2012) Atmospheric $\mathrm{CO}_{2}$ Forces Abrupt Vegetation Shifts Locally, But Not Globally. Nature, 488, 209-212.

https://doi.org/10.1038/nature11238

[46] Ayres, M.P. (1993) Plant Defense, Herbivory, and Climate Change. In: Kareiva, P.M., Kingsolver, J.G. and Huey, R.B., Eds., Biotic Interactions and Global Change, Sinauer, Sunderland, 75-94.

[47] Bardgett, R.D. and Wardle, D.A. (2010) Aboveground-Belowground Linkages: Biotic Interactions, Ecosystem Processes, and Global Change. Oxford University Press, Oxford.

[48] Jactel, H., Petit, J., Desprez-Loustau, M.L., Delzon, S., Piou, D., Battisti, A. and Koricheva, J. (2012) Drought Effects on Damage by Forest Insects and Pathogens: A Meta-Analysis. Global Change Biology, 18, 267-276. https://doi.org/10.1111/j.1365-2486.2011.02512.x

[49] Rackham, O. and Moody, J.A. (1996) The Making of the Cretan Landscape. Manchester University Press, Manchester, 237.

[50] Calama, R., Tome, M., Sanchez-Gonzalez, M., Miina, J., Spanos, K.A. and Palahi, M. (2010) Modelling Non-Wood Products in Europe: A Review. Forest Systems, 19, 69-85. https://doi.org/10.5424/fs/201019S-9324

[51] Spanos, K.A., Gaitanis, D. and Spanos, I. (2010) Resin Production in Natural Aleppo Pine Stands in Northern Evia, Greece. Web Ecology, 10, 38-43.

https://doi.org/10.5194/we-10-38-2010

[52] Petrakis, P.V., Spanos, K. and Feest, A. (2011) Insect Biodiversity Reduction of Pinewoods in Southern Greece Caused by the Pine Scale (Marchalina hellenica). Forest Systems, 20, 27-41. https://doi.org/10.5424/fs/2011201-8924

[53] Baloutsos, G. and Roussos, A. (2015) Streamflow Generation Mechanisms in Forest Watersheds and Their Contribution to Water Exploitation and to Protection of the Mountain Natural Environment. Geotechnical Scientific Issues, 24, 4-22.

[54] Díaz, S., Demissew, S., Carabias, J., Joly, C., Lonsdale, M., Ash, N., Larigauderie, A., Adhikari, J.R., Arico, S., Báldi, A. and Bartuska, A. (2015) The IPBES Conceptual Framework-Connecting Nature and People. Current Opinion in Environmental Sustainability, 14, 1-16. https://doi.org/10.1016/j.cosust.2014.11.002

[55] Shumi, G., Rodrigues, P., Hanspach, J., Härdtle, W., Hylander, K., Senbeta, F., Fischer, J. and Schultner, J. (2020) Woody Plant Species Diversity as a Predictor of Ecosystem Services in a Social-Ecological System of Southwestern Ethiopia. Landscape Ecology, 36, 1-19. https://doi.org/10.1007/s10980-020-01170-x

[56] Skov, F. and Svenning, J.C. (2004) Potential Impact of Climatic Change on the Distribution of Forest Herbs in Europe. Ecography, 27, 366-380. https://doi.org/10.1111/j.0906-7590.2004.03823.x

[57] Tinner, W. and Lotter, A.F. (2006) Holocene Expansions of Fagus silvatica and $A b$ ies alba in Central Europe: Where Are We after Eight Decades of Debate? Quaternary Science Reviews, 25, 526-549. https://doi.org/10.1016/j.quascirev.2005.03.017

[58] Loarie, S.R., Duffy, P.B., Hamilton, H., Asner, G.P., Field, C.B. and Ackerly, D.D. (2009) The Velocity of Climate Change. Nature, 462, 1052-1055. https://doi.org/10.1038/nature08649

[59] Svenning, J.C. and Sandel, B. (2013) Disequilibrium Vegetation Dynamics under 
Future Climate Change. American Journal of Botany, 100, 1266-1286. https://doi.org/10.3732/ajb.1200469

[60] Bussotti, F., Ferrini, F., Pollastrini, M. and Fini, A. (2014) The Challenge of Mediterranean Sclerophyllous Vegetation under Climate Change: From Acclimation to Adaptation. Environmental and Experimental Botany, 103, 80-98.

https://doi.org/10.1016/j.envexpbot.2013.09.013

[61] Lenoir, J., Gégout, J.C., Marquet, P.A., De Ruffray, P. and Brisse, H. (2008) A Significant Upward Shift in Plant Species Optimum Elevation during the 20th Century. Science, 320, 1768-1771. https://doi.org/10.1126/science.1156831

[62] Reyer, C.P., Leuzinger, S., Rammig, A., Wolf, A., Bartholomeus, R.P., Bonfante, A., Pereira, M., et al. (2013) A Plant's Perspective of Extremes: Terrestrial Plant Responses to Changing Climatic Variability. Global Change Biology, 19, 75-89.

https://doi.org/10.1111/gcb.12023

[63] Ogaya, R. and Peñuelas, J. (2003) Comparative Field Study of Quercus ilex and Phillyrea latifolia: Photosynthetic Response to Experimental Drought Conditions. Environmental and Experimental Botany, 50, 137-148. https://doi.org/10.1016/S0098-8472(03)00019-4

[64] Prieto, P., Penuelas, J., Llusia, J., Asensio, D. and Estiarte, M. (2009) Effects of Long-Term Experimental Night-Time Warming and Drought on Photosynthesis, Fv/Fm and Stomatal Conductance in the Dominant Species of a Mediterranean Shrubland. Acta Physiologiae Plantarum, 31, 729-739. https://doi.org/10.1007/s11738-009-0285-4

[65] Ogaya, R., Peñuelas, J., Asensio, D. and Llusià, J. (2011) Chlorophyll Fluorescence Responses to Temperature and Water Availability in Two Co-Dominant Mediterranean Shrub and Tree Species in a Long-Term Field Experiment Simulating Climate Change. Environmental and Experimental Botany, 71, 123-127. https://doi.org/10.1016/j.envexpbot.2010.10.016

[66] Giorgi, F. (2006) Climate Change Hot-Spots. Geophysical Research Letters, 33, L08707. https://doi.org/10.1029/2006GL025734

[67] McCarthy, J.J., Canziani, O.F., Leary, N.A., Dokken, D.J. and White, K.S. (2001) Climate Change 2001: Impacts, Adaptation, and Vulnerability: Contribution of Working Group II to the Third Assessment Report of the Intergovernmental Panel on Climate Change (Vol. 2). Cambridge University Press, Cambridge.

[68] Ruiz-Labourdette, D., Schmitz, M.F. and Pineda, F.D. (2013) Changes in Tree Species Composition in Mediterranean Mountains under Climate Change: Indicators for Conservation Planning. Ecological Indicators, 24, 310. https://doi.org/10.1016/j.ecolind.2012.06.021

[69] Solomou, A., Proutsos, N., Karetsos, G. and Tsagari, C. (2017) Effects of Climate Change on Vegetation in Mediterranean Forests: A Review. International Journal of Environment, Agriculture and Biotechnology, 2, 240-247. https://doi.org/10.22161/ijeab/2.1.31

[70] Founda, D. and Giannakopoulos, C. (2009) The Exceptionally Hot Summer of 2007 in Athens, Greece-A Typical Summer in the Future Climate? Global and Planetary Change, 67, 227-236. https://doi.org/10.1016/j.gloplacha.2009.03.013

[71] Spanos, K., Grigoriadis, N., Meliadis, I., Gaitanis, D. and Grigoriadis, S. (2012) The Importance and Conservation Values of Beech Forests in Greece-Case Study of an Ancient Beech Forest in the NATURA Area "Koula-Haidou" in Xanthi, N. Greece. In: Knapp, H.D. and Fichtner, A., Eds., Beech Forests-Joint Natural Heritage of Europe (2), BfN-Skripten 327, Bonn, 141-163. 
[72] Petrakis, P.V., Spanos, K., Kalapnida, M., Lahlou, E. and Feest, A. (2011) Insect Biodiversity Reduction of Pinewoods in Southern Greece Caused by the Pine Scale (Marchalina hellenica). Forest Systems, 20, 27-41. https://doi.org/10.5424/fs/2011201-8924

[73] Koulelis, P.P. (2009) Cluster Analysis in Primary Roundwood Production of 25 Countries of European Union. Annals of Forest Research, 52, 163-168.

[74] Koulelis, P. (2012) A Study of the Greek Trade Deficit in Forest Products. Current Conditions and Prospects. Forest Systems, 21, 549-554. https://doi.org/10.5424/fs/2012213-02776

[75] Hellenic Statistical Authority (ELSTAT) (2016) Main Page. Statistics.gr. http://www.statistics.gr/en/home

[76] Chalikias, M.S., Kyriakopoulos, G.L., Goulionis, J.E. and Apostolidis, G.K. (2012) Investigation of the Parameters Affecting Fuel Woods' Consumption in the Southern Greece Region. Journal of Food, Agriculture and Environment, 10, 885-889.

[77] Spanos, K.A. (2006) Short Rotation Forestry-Forest Biomass Production from Fast Growing Forest Plantations, Possibilities for Energy and Chemical Use. 8th National Conference for Renewable Energy, Thessaloniki, 29-31 March 2006, 461-468.

[78] Koulelis, P.P. (2016) Forest Products Consumption and Trade Deficit in Greece during the Financial Crisis: A Quantitative Statistical Analysis. Open Journal of Business and Management, 4, 258-265. https://doi.org/10.4236/ojbm.2016.42027

[79] Ministry of Environment Press Office (2018) National Forest Strategy. Ministry of Environment and Energy, Press Office. http://www.ypeka.gr

[80] Tsiaras, S., Koulelis, P., Tsiroukis, A. and Spanos, I. (2020) The Contribution of Forests in Regional Development: The Role of National Forest Strategy in Greece. MIBES Transactions Journal, 14, 110-122. http://mibes.uth.gr/vol14_issue1_2020.html

[81] Eurostat (2019) Annual National Accounts_nama10. Eurostat, the Statistical Office of the European Union, Metadata Last Update 8/4/2019.

[82] Spanos, K.A. (2013) Paulownia-A Valuable Forest Tree for Alternative Cultivation and Future Investment. Hellenic Agricultural Organization, Dimitra, Issue 3, 13-16.

[83] Koulelis, P.P. (2017) Restructuring the Greek Forest Sector in Order to Facilitate Rural Development in Greece. In: Theodoridis, A., Ragkos, A. and Salampasis, M., Eds., International Conference on Information and Communication Technologies in Agriculture, Food and Environment, Springer, Cham, 23-35.

https://doi.org/10.1007/978-3-030-02312-6_2 